\title{
Biofilm cultivation of marine dinoflagellates under different temperatures and nitrogen regimes enhances DHA productivity
}

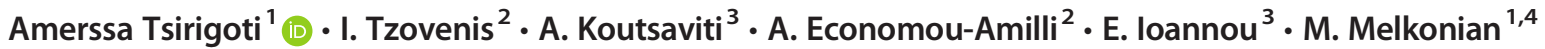

Received: 22 October 2019 / Revised and accepted: 17 December 2019 / Published online: 20 January 2020

(C) The Author(s) 2020

\begin{abstract}
Dinoflagellates contain large amounts of omega-3 fatty acids, including the nutritionally important docosahexaenoic acid (DHA). However, their cultivation in suspensions is characterized by low growth rates. Twin-layer porous substrate photobioreactors (TL-PSBRs) have been shown to support growth of different microalgal species, including the robust dinoflagellate Symbiodinium voratum. In the present study, the potential of cultivating marine autotrophic dinoflagellate species in a TLPSBR for DHA production was explored. Based on initial screening experiments, two Symbiodinium species with high biomass and DHA productivities were selected: the symbiotic Symbiodinium microadriaticum CCAC 2475 B and the free-living Symbiodinium voratum CCAC 3869 B. The effects of three different temperatures (17, 22 and $\left.27{ }^{\circ} \mathrm{C}\right)$ and nitrogen regimes (nitrate, ammonium and nitrogen-free) on biomass growth, total lipid accumulation and fatty acid methyl esters (FAMEs) content, with emphasis on DHA, were evaluated. The two lower temperatures $\left(17\right.$ and $\left.22^{\circ} \mathrm{C}\right)$ enhanced growth and total lipid accumulation of S. microadriaticum CCAC 2475 B and S. voratum CCAC 3869 B. Cultivation at $22{ }^{\circ} \mathrm{C}$ and nitrogen limitation led to a significant positive effect on DHA productivity. Symbiodinium. microadriaticum CCAC 2475 B reached a DHA productivity of $145.4 \mathrm{mg} \mathrm{m}^{-2}$ day $^{-1}$ and DHA content in the dry biomass of $2 \%(w / w)$ after 4 days of nitrogen depletion. The results of the present study demonstrated that autotrophic dinoflagellates, when cultivated on a TL-PSBR, produce comparable amounts of lipids and fatty acids to other commercially used microalgal species including the valuable DHA.
\end{abstract}

Keywords Autotrophic dinoflagellates $\cdot$ Symbiodinium $\cdot$ Biofilm cultivation $\cdot$ Photobioreactor $\cdot$ Twin-layer $\cdot$ DHA

\section{Introduction}

Essential omega-3 long chain poly-unsaturated fatty acids (PUFAs), particularly docosahexaenoic acid (DHA, 22:6w3),

Electronic supplementary material The online version of this article (https://doi.org/10.1007/s10811-019-02027-w) contains supplementary material, which is available to authorized users.

Amerssa Tsirigoti

amerssa@hotmail.com

1 Botanisches Institut, Biozentrum Köln, Universität zu Köln, Zülpicher Str. 47 b, 50674 Köln, Germany

2 Section of Applied Phycology, Ecology \& Systematics, Department of Biology, National and Kapodistrian University of Athens, Panepistimiopolis Zografou, 15784 Athens, Greece

3 Section of Pharmacognosy \& Chemistry of Natural Products, Department of Pharmacy, National and Kapodistrian University of Athens, Panepistimiopolis Zografou, 15771 Athens, Greece

4 Present address: Faculty of Biology, University of Duisburg-Essen, Campus Essen, Universitätsstr. 2, 45141 Essen, Germany exhibit significant biological activities therapeutically relevant to a plethora of human diseases, such as coronary heart disease, cancer, type 1 diabetes and rheumatoid arthritis (Simopoulos 2008; Swanson et al. 2012; Nestel et al. 2015). Recently, the use of omega-3 supplements was included in the European Society of Cardiology (ESC) guidelines for cardiovascular disease prevention and heart failure treatment (Ponikowski et al. 2016). Therefore, DHA attracts increasing commercial interest as a standard nutritional element of the human diet. Moreover, the importance of DHA for the normal growth of larval fish, shrimps and molluscs in aquaculture has been well established (Benemann 1992; Barclay and Zeller 1996; Patil et al. 2005; Nath et al. 2012).

Hitherto, fish oil has monopolized the market as the only commercial source of omega-3 PUFAs (Pike and Jackson 2010). However, the distractive odour, accumulation of toxins, allergic reactions, high refinery costs and limited resources are among the major drawbacks calling for alternative supplies (Mahaffey et al. 2008; Tacon and Metian 2008; Bourdon et al. 2010; Sun et al. 2018; Tocher et al. 2019). Microalgae have been known for decades to be the primary 
sources of omega-3 PUFAs for organisms at higher levels of the aquatic food web (Brett and Müller-Navarra 1997; Dalsgaard et al. 2003; Müller-Navarra 2008). Increasing research efforts mostly devoted to the commercialization of algae for biofuel production (Chisti 2007, 2013; Shuba and Kifle 2018) but also various techno-economic analysis reports (Chauton et al. 2015; Khan et al. 2018; Shah et al. 2018), support the feasibility of industrial algae cultivation. However, to market important products, such as DHA produced by autotrophic microalgae, several limitations and challenges responsible for low biomass productivities still need to be overcome. Recognizing these problems, several research groups turned their attention towards the development of fermentation technologies for the cultivation of heterotrophic "microalgae"/protists (Leyland et al. 2017) that offer rapid growth and lower cost of biomass harvesting (Mendes et al. 2009; Ren et al. 2010; Liu et al. 2014). Nevertheless, the interest in photoautotrophic algae for PUFA-rich oils did not diminish (Ryan and Symington 2015; Jónasdóttir 2019; Wang et al. 2019). Photosynthetic production is renewable by definition, sustaining the global ecosystem and economy (Janssen et al. 2014); hence, photosynthetic algal production does not compete with agriculture (Singh et al. 2011). Moreover, a series of studies, comparing heterotrophic versus autotrophic food resources, interestingly revealed that, e.g. ciliates and heterotrophic dinoflagellates are not nutritionally superior prey for marine copepods than the autotrophs (Broglio et al. 2003; Breteler et al. 2004).

Dinoflagellates contain high levels of omega-3 PUFAs, especially DHA. Their cultivation in suspension, however, suffers from low growth rates and is frequently hampered by their sensitivity to shear stress (Dixon and Syrett 1988; Gibson and Thomas 1995; Gallardo-Rodríguez et al. 2009; LópezRosales et al. 2015; Wang and Lan 2018), although continuing efforts are being made to address these issues using either open or closed cultivation systems (Fuentes-Grünewald et al. 2016; Molina-Miras et al. 2018; López-Rodríguez et al. 2019). Cell immobilization using a twin-layer porous substrate photobioreactor (TL-PSBR) was recently applied successfully to the peridinin-producing marine dinoflagellate Symbiodinium voratum, which resulted in much higher growth rates compared to a suspension culture (Benstein et al. 2014; Langenbach and Melkonian 2019). Herein, we introduce the idea of cultivating marine autotrophic dinoflagellate species in a TL-PSBR for the production of DHA. Based on initial screening experiments, we selected two Symbiodinium species with high biomass and DHA productivities: the symbiotic Symbiodinium microadriaticum LaJeunesse and the free-living Symbiodinium voratum H.J.Jeong, S.Y.Lee, N.S.Kang \& LaJeunesse. The effect of different temperatures and nitrogen sources/limitation on the growth, total lipid accumulation and DHA content was investigated. The DHA productivities achieved were comparable to those obtained by other commercially used microalgal species, suggesting that this novel approach could potentially have industrial applications.

\section{Material and methods}

\section{Species selection, suspension culture and culture media}

All marine autotrophic dinoflagellate strains were provided by the Culture Collection of Algae at the University of Cologne (CCAC, Department of Botany, University of Cologne, Germany; www.ccac.uni-koeln.de; from October 2019: Central Collection of Algal Cultures, University of Duisburg-Essen). For the initial screening tests, 38 different dinoflagellate strains were used (Supplementary Table 1), and the experiments were conducted in a 96-well twin-layer system (Phycomat; Nowack et al. 2005). Seven of these strains and three Symbiodinium strains (Table 1) were selected for further investigation in a bench-scale TL-PSBR (Fig. 1). All stock cultures were grown in suspension in $100 \mathrm{~mL}$ Erlenmeyer flasks at $22{ }^{\circ} \mathrm{C}$ with $40 \pm 15 \mu \mathrm{mol}$ photons

Table 1 List of the ten marine dinoflagellate strains selected for the experiments in the bench-scale vertical TL-PSBR

\begin{tabular}{lll}
\hline Species & CCAC strain number & Family \\
\hline Calcigonellum infula & CCAC 4764 B & Thoracosphaeraceae \\
Kryptoperidinium sp. & CCAC 4765 B & Dinotrichaceae \\
Heterocapsa niei & UTEX LB 1564 & Heterocapsaceae \\
Heterocapsa pygmaea & CCAC 3918 B & Heterocapsaceae \\
Heterocapsa pygmaea & CCAC 3919 B & Heterocapsaceae \\
Heterocapsa pygmaea & CCAC 3920 B & Heterocapsaceae \\
Scrippsiella acuminata & CCAC 4745 B & Thoracosphaeraceae \\
Symbiodinium voratum & CCAC 0047 & Suessiaceae \\
Symbiodinium voratum & CCAC 3869 B & Suessiaceae \\
Symbiodinium microadriaticum & CCAC 2475 B & Suessiaceae \\
\hline
\end{tabular}




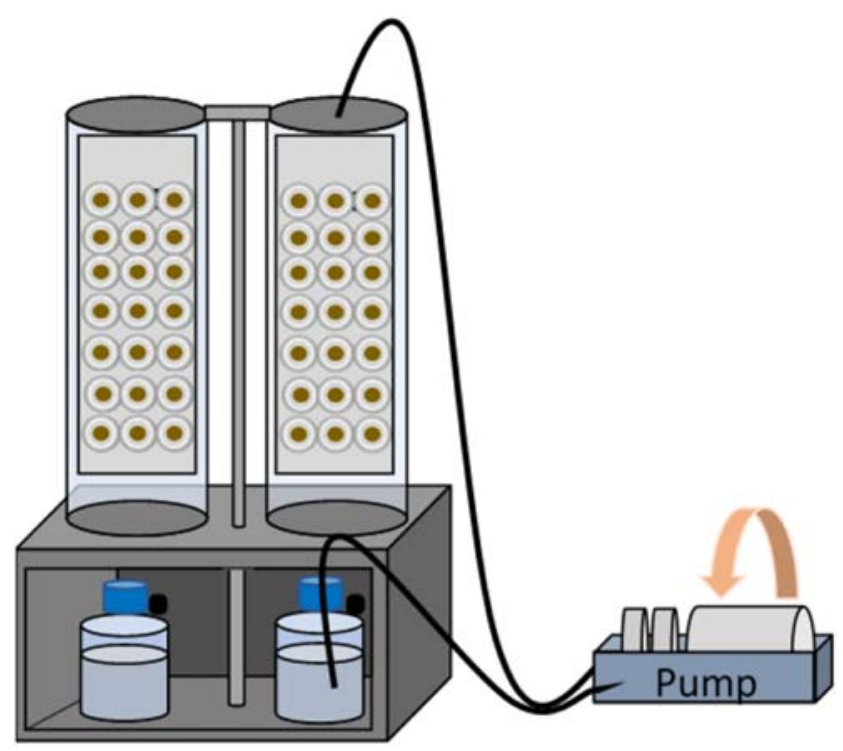

Fig. 1 Schematic representation of the bench-scale vertical twin-layer porous substrate photobioreactor

$\mathrm{m}^{-2} \mathrm{~s}^{-1}$ provided by fluorescent lamps (L36 W/640i energy saver cool white and L58 W/956 BioLux fluorescent lamps; Osram, Germany), using a 14:10 h light:dark cycle and no aeration. In order to inoculate the Phycomat and the benchscale TL-PSBR, the suspension cultures were transferred to larger Erlenmeyer flasks $(0.5-2 \mathrm{~L})$ and harvested from the logarithmic growth phase. The dinoflagellate strains used for the initial screening experiments (Supplementary Table 1) were grown, depending on the strain, in artificial seawater medium ASP-12 modified by McFadden and Melkonian (1986), in modified ASP-12 enriched with soil extract (10 mL per litre of ASP-12) or in L1 medium (Guillard and Hargraves 1993) according to CCAC strain data. All ten strains used for the experiments in the bench-scale vertical TL-PSBR were grown in L1 medium. A variation of the L1 medium was used for a series of growth experiments in TLPSBRs, in which nitrate was substituted by ammonium maintaining the same concentration of nitrogen in the medium. The effect of nitrogen limitation was tested by replacing the L1 medium with a modified version of it, containing no nitrogen source after the first 8 days of the experiment. The $\mathrm{pH}$ of all media was adjusted to 7.8 .

\section{Immobilized cultivation}

\section{Phycomat}

A 96-well Twin Layer system, the Phycomat, was used for the initial screening tests as described by Nowack et al. (2005). The Phycomat is a small-scale horizontally orientated twinlayer system designed for the cultivation of immobilized algae in a 96-well format. It consists of a cultivation chamber, boreholes plugged with rubber for the exchange of the medium and a glass cover. A stack of eight layers of glass fibre sheets ( $80 \mathrm{~g} \mathrm{~m}^{-2}$, Isola AS, Eidanger, Norway) functions as a reservoir of the culture medium (source layer of the system), and a 96-well "MultiScreen" filter plate is used as a substrate layer for the cultivation of microalgae (for more details, see Nowack et al. 2005). Each strain was tested in four replicates, and the inoculation procedure followed Nowack et al. (2005). A dense suspension culture was transferred to inoculate the wells of the Phycomat, and the experiment was run for 8 weeks. The culture medium was changed once per week under aseptic conditions using sterile disposable $50 \mathrm{~mL}$ syringes. For each strain, growth and viability were monitored by visual inspection and the possibility of re-establishment of suspension cultures.

\section{Bench-scale TL-PSBR}

The bench-scale vertical TL-PSBR (Fig. 1) used in the present study was described by Schultze et al. (2015), based on the design by Shi et al. (2007). Briefly, the system consists of two transparent poly-methyl methacrylate (PMMA, Plexiglas) tubes (50 cm long, $12 \mathrm{~cm}$ diameter) located on top of a polyvinylchloride (PVC) base. Inside each tube, a glass fibre sheet (40 $\mathrm{cm}$ long, $10 \mathrm{~cm}$ width, $80 \mathrm{~g} \mathrm{~m}^{-2}$, Isola AS, Norway) serves as the source layer. The source layer is covered by numerous removable discs $(25 \mathrm{~mm}$ diameter, plain printing paper, $45 \mathrm{~g} \mathrm{~m}^{-2}$, Mediengruppe M. DuMontSchauberg GmbH \& Co. KG, Cologne, Germany) that represent the microporous substrate layer for the cultivation of the immobilized microalgae. The L1 culture medium is stored in 1 L Duran bottles (Duran, Germany) at the PVC base of the system and is continuously circulated by a peristaltic pump. It is applied at the top of the glass fibre sheet, traverses through it due to gravity, recollected to the $1 \mathrm{~L}$ Duran bottle and recycled. A flow rate of $1.25 \pm 0.25 \mathrm{~L} \mathrm{~m}^{-2} \mathrm{~h}^{-1}$ was used to maintain the glass fibre sheet wet, while the culture medium was exchanged every $4-5$ days to avoid nutrient depletion. The evaporation rate $\left(0.008-0.06 \mathrm{~mL} \mathrm{~min}^{-1}\right.$ depending on the temperature used during cultivation) was monitored by recording the change of the volume in the medium container. Loss of water by evaporation was replaced regularly by deionized water to adjust the salinity of the culture medium. Aeration was supplied inside from the bottom of the Plexiglas tube at a flow rate of $1.0 \mathrm{~L} \mathrm{~min}^{-1}$ of ambient air. The temperatures used for the experiments were $17 \pm 1,22 \pm 1$ and $27 \pm 1^{\circ} \mathrm{C}$, and the photon flux density was $200 \pm 15 \mu \mathrm{mol}$ photons $\mathrm{m}^{-2} \mathrm{~s}^{-1}$ (LI-COR, USA) provided by fluorescent lamps (L36 W/865 cool day light, OSRAM), at a 14:10 h light:dark cycle.

For the inoculation of the TL-PSBR, dinoflagellate suspension cultures with a density of $200 \mathrm{mg}$ dry mass $\mathrm{L}^{-1}$ were concentrated by centrifugation at $200 \mathrm{xg}$ for $10 \mathrm{~min}$ and then filtered onto the paper discs as described by Naumann et al. 
(2013). Initial biomass density (IBD) was $5 \mathrm{~g}$ dry weight $\mathrm{m}^{-2}$ growth area. The inoculated wet filters were then placed on the wet glass fibre sheets in the TL-PSBR. At each sampling point, three filters per strain were collected from each TLPSBR, rinsed successively with $4 \%$ ammonium formate in three steps to remove remaining salts from marine media and freeze-dried. Dry weight was determined gravimetrically, and biomass was stored at $-20{ }^{\circ} \mathrm{C}$ until lipid extraction. All experiments were repeated at least twice with similar results.

\section{Lipid extraction}

The algal biomass was extracted in $\mathrm{CH}_{2} \mathrm{Cl}_{2}: \mathrm{MeOH}: \mathrm{H}_{2} \mathrm{O}$ $(1: 2: 0.8, \mathrm{v} / \mathrm{v} / \mathrm{v})$ using a modified protocol of the Bligh and Dyer (1959). Extraction was performed using successive vortexing and ultrasonication in Teflon-lined screw-capped glass vials. To achieve phase separation, $\mathrm{CH}_{2} \mathrm{Cl}_{2}$ and $\mathrm{ddH}_{2} \mathrm{O}$ (Milli-Q system) were added to the extract to give a final $\mathrm{CH}_{2} \mathrm{Cl}_{2}: \mathrm{MeOH}: \mathrm{H}_{2} \mathrm{O}$ ratio of 1:1:0.9 (v/v/v). The $\mathrm{CH}_{2} \mathrm{Cl}_{2}$ layer was then transferred through glass pipettes plugged with cotton and containing anhydrous sodium sulphate to preweighted $2 \mathrm{~mL}$ glass vials and dried to constant mass under a nitrogen stream. The total lipid content was determined gravimetrically. The extracts were reconstituted in $\mathrm{CH}_{2} \mathrm{Cl}_{2}$ to prepare lipid stock solutions $\left(10 \mathrm{mg} \mathrm{mL}^{-1}\right)$ that were stored under nitrogen at $-20^{\circ} \mathrm{C}$ until further analysis.

\section{Fatty acid derivatization}

Fatty acid methyl esters (FAME) were prepared by transesterification of the lipid stock solutions. Briefly, $50 \mu \mathrm{g}$ of C17:0 fatty acid was added as internal standard to each lipid extract. After addition of $3 \mathrm{~mL}$ of $5 \%$ acetyl chloride in anhydrous methanol, the mixtures were heated at $80^{\circ} \mathrm{C}$ for $1 \mathrm{~h}$. After cooling, $2 \mathrm{~mL}$ of $\mathrm{ddH}_{2} \mathrm{O}$ was added. FAME were extracted after addition of $2 \mathrm{~mL}$ of cyclohexane. The FAMEcontaining cyclohexane layer was transferred to a glass vial, flushed with nitrogen, sealed with a Teflon-lined screw cap and stored at $-20^{\circ} \mathrm{C}$ until further analysis.

\section{Gas chromatography-mass spectrometry (GC-MS) analysis}

The analyses of FAME were carried out using an Agilent Technologies $7820 \mathrm{~A}$ gas chromatograph equipped with a HP-5MS fused silica capillary column $(30 \mathrm{~m} \times 0.25 \mathrm{~mm}$, $0.25 \mu \mathrm{m}$ ), an Agilent Technologies 5977B MS detector operating in electron ionization mode at $70 \mathrm{eV}$ and an Agilent Technologies 7693A automatic liquid sampler. The GC-MS conditions for the analyses were the following: a split/splitless inlet at $280{ }^{\circ} \mathrm{C}$ was used at a split ratio $3: 1$; the carrier gas was $\mathrm{He}$ at a constant flow rate of $1.2 \mathrm{~mL} \mathrm{~min}^{-1}$; the oven temperature was $100{ }^{\circ} \mathrm{C}$ at the time of the injection, raised to $150{ }^{\circ} \mathrm{C}$ at a rate of $8{ }^{\circ} \mathrm{C} \mathrm{min}^{-1}$, then raised to $200{ }^{\circ} \mathrm{C}$ at a rate of $1{ }^{\circ} \mathrm{C} \min ^{-1}$, subsequently raised to $300{ }^{\circ} \mathrm{C}$ at a rate of $10{ }^{\circ} \mathrm{C} \mathrm{min}{ }^{-1}$ and finally maintained at $300{ }^{\circ} \mathrm{C}$ for $3.75 \mathrm{~min}$; the MSD transfer line was set at $280^{\circ} \mathrm{C}$; the source temperature was set at $230^{\circ} \mathrm{C}$, while the quadrupole temperature was set at $150{ }^{\circ} \mathrm{C}$. MassHunter software (Agilent) was used for data acquisition and analysis. The identification of the chemical constituents was based on comparison of their Kováts indices, relative retention times and mass spectra with those obtained from authentic standards (Sigma Chemical Co., USA; PhytoLab GmbH and Co., Germany, and in-house isolated and identified metabolites) and/or reported in the NIST/ NBS and Wiley libraries.

\section{Data analysis}

The slopes of linear regression were used for all calculations of growth rates and DHA productivities, considering only the linear periods. Values shown in the figures are expressed as mean \pm SD of at least 3 replicates. To statistically compare growth rates of algae at different experimental conditions, analysis of covariance (ANCOVA) was employed to compare slopes of linear growth phases. All data analysis was performed using the GraphPad Prism v5.04 statistical software (GraphPad Software Inc., USA).

\section{Results}

\section{Screening marine dinoflagellate strains for immobilized cultivation on twin-layer porous substrate photobioreactors}

Initial screening of 38 marine dinoflagellate strains (Supplementary Table 1) was performed in a 96-well TwinLayer system to investigate growth under immobilized conditions. Monitoring for 8 weeks revealed that the strains Calcigonellum infula CCAC 4764 B, Kryptoperidinium sp. CCAC 4765 B, Heterocapsa niei UTEX LB 1564, Heterocapsa pygmaea CCAC 3918 B, Heterocapsa pygmaea CCAC 3919 B, Heterocapsa pygmaea CCAC 3920 B and Scrippsiella acuminata CCAC 4745 B (formerly Scrippsiella trochoidea) grew successfully on the 96-well twin-layer system. Tests for re-establishing suspension cultures were accomplished in triplicates per strain to confirm the visual observations. Subsequently, the above-mentioned strains were cultivated in a bench-scale TL-PSBR, together with three Symbiodinium strains: Symbiodinium voratum CCAC 0047, Symbiodinium voratum CCAC 3869 B and Symbiodinium microadriaticum CCAC 2475 B. Figure 2 shows that the dinoflagellates tested in the bench-scale TLPSBR revealed significant differences in biomass production, with the three Symbiodinium strains reaching the highest 
Fig. 2 Total biomass in $\mathrm{g} \mathrm{m}^{-2}$ $(n=3 \pm \mathrm{SD})$ of ten different immobilized dinoflagellate cultures in TL-PSBRs within an experimental period of 21 days at $22{ }^{\circ} \mathrm{C}$

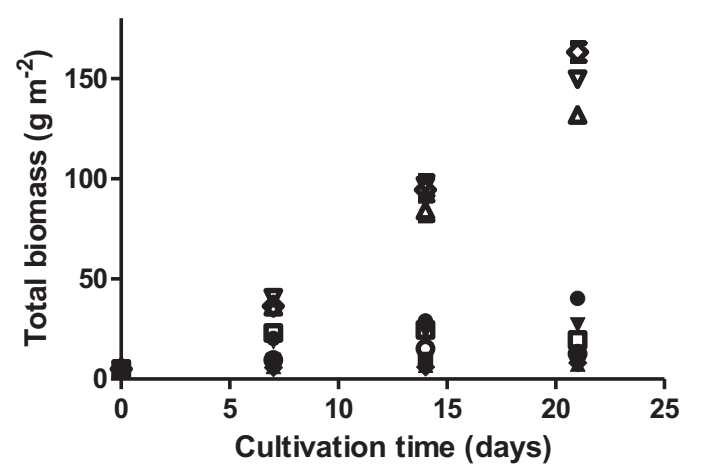

Heterocapsa niei UTEX LB 1564
Kryptoperidinium sp. CCAC 4765 B
Heterocapsa pygmaea CCAC 3918 B
Heterocapsa pygmaea CCAC 3919 B
Heterocapsa pygmaea CCAC 3920 B
Calcigonellum infula CCAC 4764 B
Scrippsiella trochoidea CCAC 4745 B
Symbidionium voratum CCAC 0047
Symbidionium voratum CCAC 3869 B
Symbiodinium microadriaticum CCAC
2475 B standing crop in the range of 131.8-163.1 $\mathrm{g}$ dry weight $\mathrm{m}^{-2}$ after 21 days of cultivation. For the Symbiodinium strains, growth between days 7 and 21 was almost linear with an average biomass growth rate between $6.8-9.1 \mathrm{~g} \mathrm{~m}^{-2}$ day $^{-1}$ (Fig. 2). Immobilized cultivation of the H. pygmaea strains was not successful in the TL-PSBR under the aforementioned conditions (Fig. 2). C. infula CCAC 4764 B and S. acuminata CCAC $4745 \mathrm{~B}$ showed slow growth that ceased after the first 2 weeks of the experiment (Fig. 2). Kryptoperidinium sp. CCAC $4765 \mathrm{~B}$ and H. niei UTEX LB 1564 grew slowly over the whole cultivation period (Fig. 2), reaching a maximum standing crop of $27.1 \mathrm{~g} \mathrm{~m}^{-2}$ and $40.3 \mathrm{~g} \mathrm{~m}^{-2}$, respectively. Thus, based on their promising growth potential and preliminary DHA content data from suspension cultures (not shown), the free-living S. voratum CCAC 3869 B and the symbiotic S. microadriaticum CCAC 2475 B were selected for further investigation.

\section{Effect of temperature and nitrogen source/limitation on the growth of the dinoflagellates}

Immobilized growth was investigated under three different temperatures, 17,22 and $27^{\circ} \mathrm{C}$. Biomass production in terms of dry matter per $\mathrm{m}^{2}$ was almost the same for both $S$. voratum CCAC 3869 B and S. microadriaticum CCAC 2475 B at 17 and $22^{\circ} \mathrm{C}$ during the experimental period of 14 days (Fig. 3). When cultivated at $17^{\circ} \mathrm{C}, \mathrm{S}$. voratum CCAC $3869 \mathrm{~B}$ reached a maximum standing crop of $78.0 \mathrm{~g} \mathrm{~m}^{-2}$ at day 14 of the experiment, whereas S. microadriaticum CCAC 2475 B reached $72.7 \mathrm{~g} \mathrm{~m}^{-2}$. The values of the final standing crop obtained at $22{ }^{\circ} \mathrm{C}$ were 73.0 and $66.4 \mathrm{~g} \mathrm{~m}^{-2}$, respectively. The lowest biomass production was observed at $27^{\circ} \mathrm{C}$, with $S$. voratum CCAC $3869 \mathrm{~B}$ hardly tripling its biomass $\left(14.7 \mathrm{~g} \mathrm{~m}^{-2}\right.$ at day 14) and S. microadriaticum CCAC 2475 B reaching a maximum standing crop of $34.2 \mathrm{~g} \mathrm{~m}^{-2}$ at day 14 of the experiment.

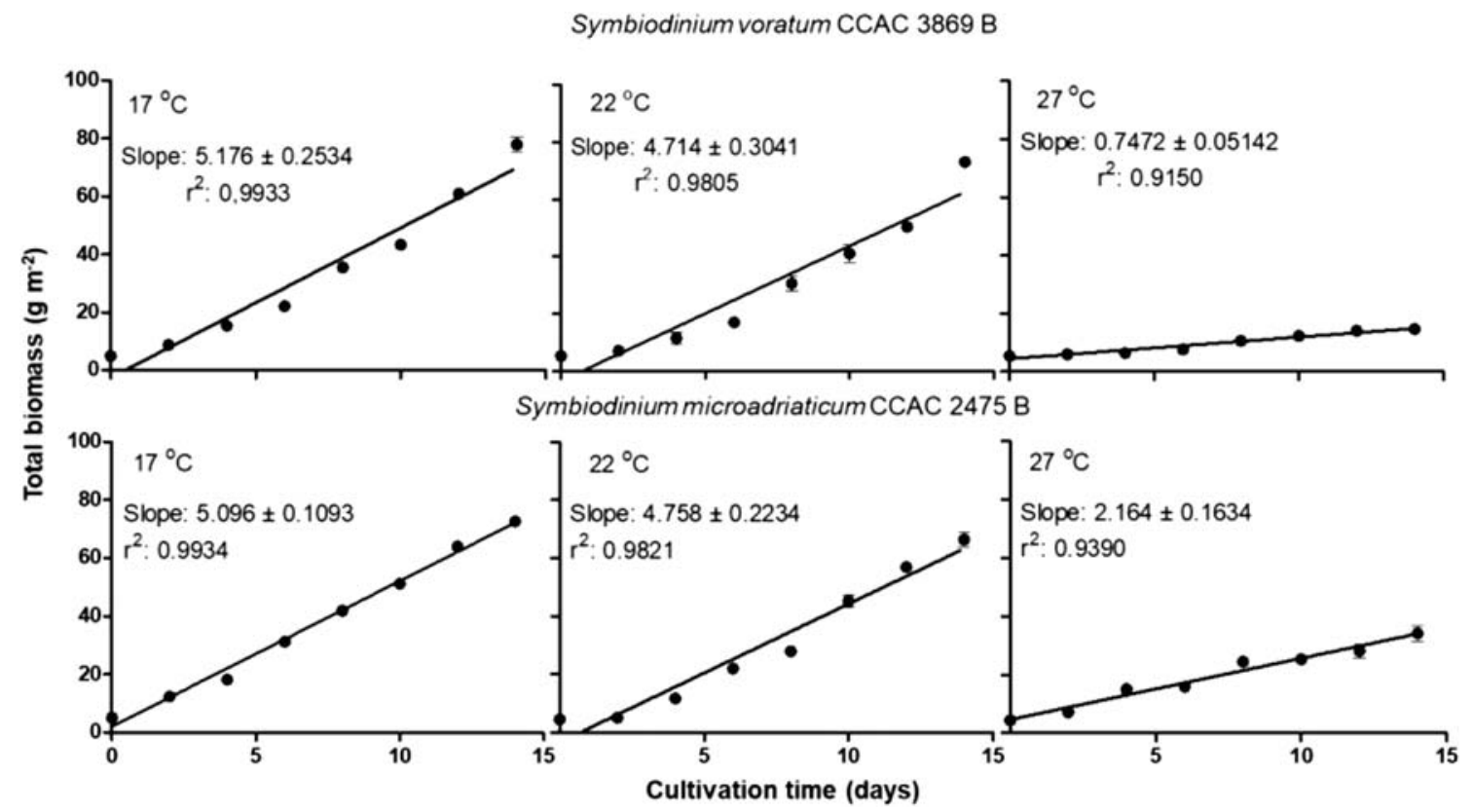

Fig. 3 Total biomass in $\mathrm{g} \mathrm{m}^{-2}(n=3 \pm \mathrm{SD})$ of immobilized Symbiodinium voratum CCAC 3869 B and Symbiodinium microadriaticum CCAC 2475 B cultures in TL-PSBRs within the experimental period of 14 days under different temperatures (17, 22 and $27^{\circ} \mathrm{C}$ ). Linear phase is indicated by the solid line 
Regarding the growth rates, the effect of temperature was significant at $27^{\circ} \mathrm{C}$ for both Symbiodinium species as revealed by the slopes in Fig. 3. The experiments with 17 and $22^{\circ} \mathrm{C}$ resulted in similar values, with the growth rates at $17^{\circ} \mathrm{C}$ being slightly higher.

Subsequently, the effect of two different nitrogen sources, i.e. nitrate and ammonium, and nitrogen limitation was tested on biomass growth. S. voratum CCAC 3869 B revealed slightly higher biomass production when cultivated with nitrate, yielding a final standing crop of $73.0 \mathrm{~g} \mathrm{~m}^{-2}$ at day 14 , while its total biomass was $66.3 \mathrm{~g} \mathrm{~m}^{-2}$ after 14 days of cultivation with ammonium (Fig. 4). In contrast, the use of ammonium increased the biomass production of $S$. microadriaticum CCAC 2475 B significantly, reaching a final standing crop of $92.2 \mathrm{~g} \mathrm{~m}^{-2}$ instead of $66.4 \mathrm{~g} \mathrm{~m}^{-2}$ after 14 days of cultivation with nitrate (Fig. 4). In the case of nitrogen limitation, in both Symbiodinium species, growth ceased after day 8 of cultivation, i.e. when the $\mathrm{L} 1$ culture medium was replaced by nitrogen-free L1 medium (Fig. 4). Growth on nitrate showed a lag phase of about 2 days in both species (Fig. 4).

Concerning the effect of different nitrogen sources on growth rates, ammonium enhanced the growth of $S$. microadriaticum CCAC $2475 \mathrm{~B}$, which reached an average growth rate of $6.263 \mathrm{~g} \mathrm{~m}^{-2}$ day $^{-1}$, whereas with nitrate, the average growth rates achieved were in the range of $4.714-4.758 \mathrm{~g} \mathrm{~m}^{-2}$ day $^{-1}$ for both species (Fig. 4). The negative effect of nitrogen limitation on biomass growth of the two dinoflagellate species was demonstrated by very low growth rates after day 8 of immobilized cultivation, i.e. when the nitrogen limitation started (Fig. 4).

\section{Effect of temperature and nitrogen source/limitation on total lipids per growth area and lipid content in the biomass}

High temperature $\left(27^{\circ} \mathrm{C}\right)$ caused a significant decrease in the amount of total lipids per area for both dinoflagellate species studied after 4 days of cultivation (Fig. 5). Symbiodinium voratum CCAC 3869 B reached its maximum value of $0.9 \mathrm{~g} \mathrm{~m}^{-2}$ at day 4 , while $S$. microadriaticum CCAC $2475 \mathrm{~B}$ maintained a stable amount of $1.2 \mathrm{~g} \mathrm{~m}^{-2}$ total lipids per area from day 4 throughout the experiment under these conditions (Fig. 5). Overall, at 17 and $22{ }^{\circ} \mathrm{C}$, total lipids per area increased during the experimental period in both species. Symbiodinium microadriaticum CCAC 2475 B, though, reached slightly higher maximum values of total lipids per area than $S$. voratum CCAC 3869 B (2.4-2.8 $\mathrm{g} \mathrm{m}^{-2}$ compared to 2.0-2.2 $\mathrm{g} \mathrm{m}^{-2}$; Fig. 5). Regarding lipid content in the dry biomass, values decreased over time for all temperatures and both dinoflagellate species studied (Fig. 5). The highest lipid content in the dry biomass was $12.8 \%(w / w)$ for $S$. voratum CCAC $3869 \mathrm{~B}$ at day $4,22{ }^{\circ} \mathrm{C}$ and $8.8 \%$ for $S$. microadriaticum CCAC $2475 \mathrm{~B}$ at day $4,27^{\circ} \mathrm{C}$ (Fig. 5).

The effect of different nitrogen sources (nitrate versus ammonium) on total lipids per area was proven insignificant (Fig. 6). The Symbiodinium species demonstrated an increase in the amount of total lipids over time and reached maximum values in the range of 2.2-2.4 $\mathrm{g} \mathrm{m}^{-2}$ with both nitrate and ammonium (Fig. 6). Nitrogen limitation, however, contributed to the accumulation of total lipids, and thus, the two dinoflagellates showed

\section{Symbiodinium voratum CCAC 3869 B}

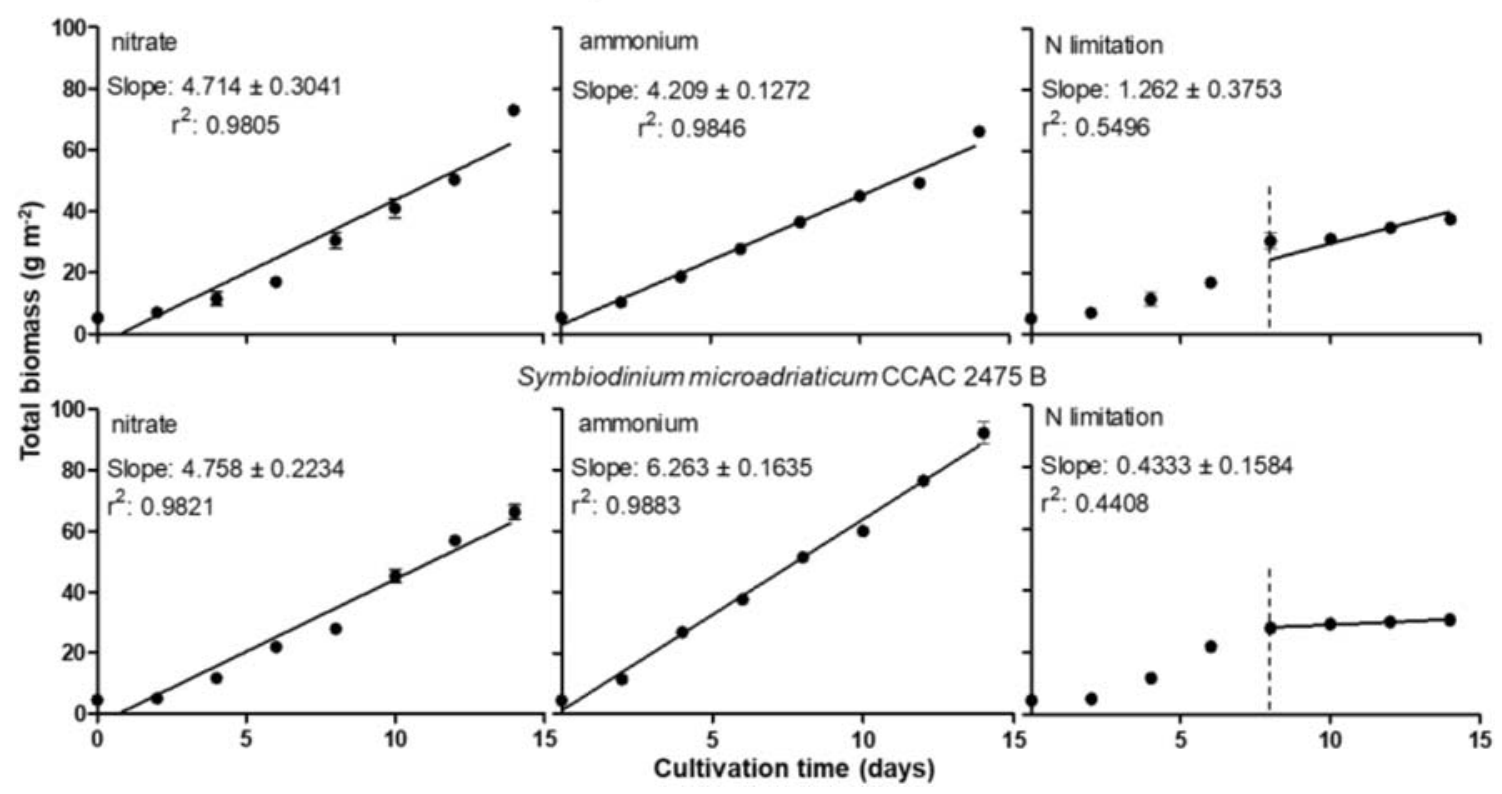

Fig. 4 Total biomass in $\mathrm{g} \mathrm{m}^{-2}(\mathrm{n}=3 \pm \mathrm{SD})$ of immobilized Symbiodinium voratum CCAC 3869 B and Symbiodinium experimental period of 14 days under different nitrogen regimes (nitrate, ammonium, nitrogen limitation) at $22{ }^{\circ} \mathrm{C}$. Nitrogen limitation started at day 8 (vertical dashed line). The linear phase is indicated by the solid line 
Symbiodinium voratum CCAC 3869 B

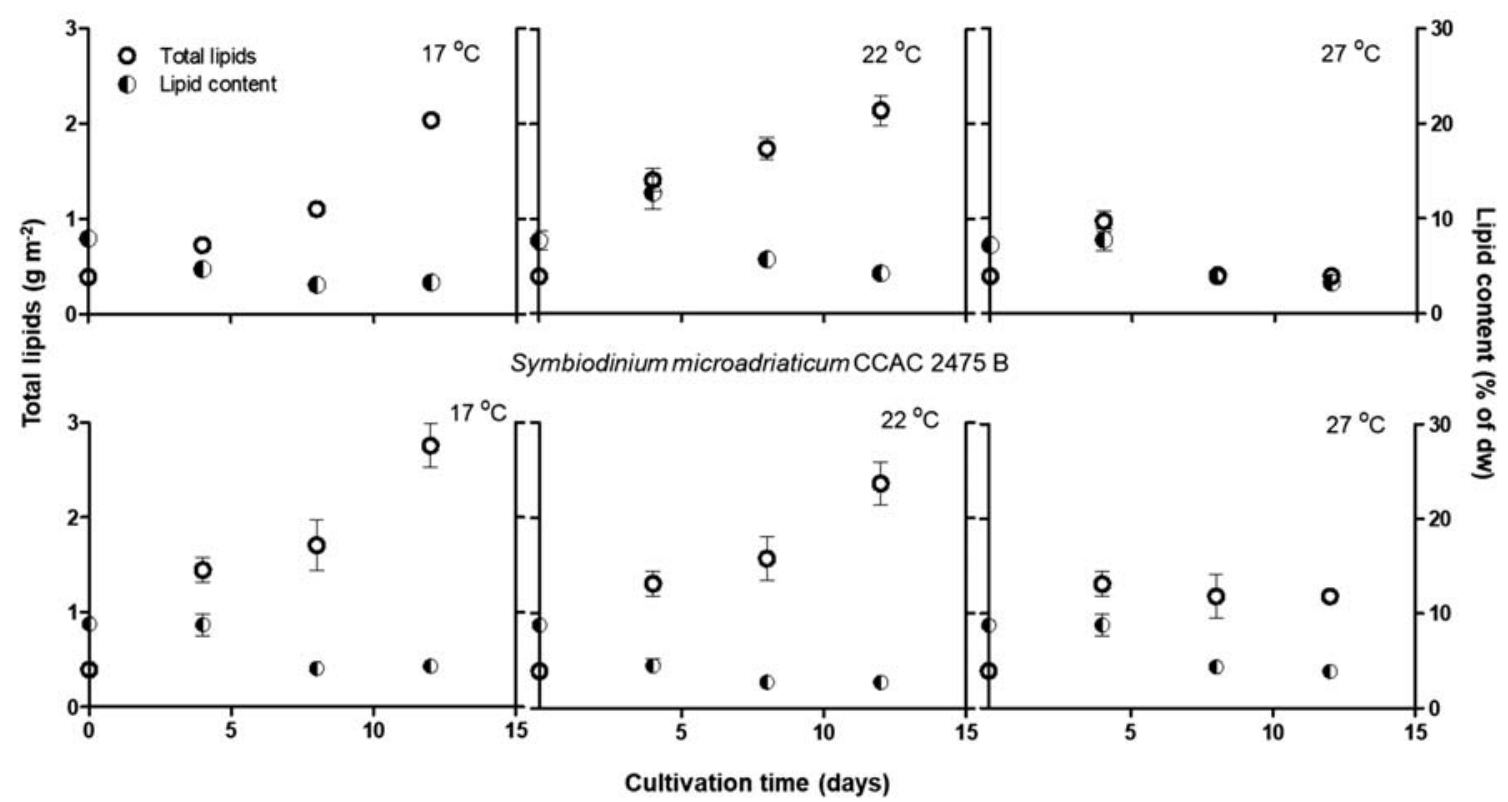

Fig. 5 Total lipids $\left(\mathrm{g} \mathrm{m}^{-2}\right.$ ) and lipid content (\% of the dry weight) of immobilized Symbiodinium voratum CCAC 3869 B and Symbiodinium microadriaticum CCAC $2475 \mathrm{~B}$ cultures in TL-PSBRs within the experimental period under different temperatures $\left(17,22\right.$ and $\left.27^{\circ} \mathrm{C}\right)$

higher maximum values in the range of $2.9-3.2 \mathrm{~g} \mathrm{~m}^{-2}$ (Fig. 6). In the case of lipid content, the effect of nitrate and ammonium was negligible, with $S$. voratum CCAC 3869 B ending up with $4.4 \%$ and S. microadriaticum CCAC 2475 B with $2.8 \%$ lipid content in the dry weight after 12 days of immobilized cultivation (Fig. 6). On the contrary, nitrogen limitation had a positive effect on the lipid content which increased to $9.3 \%$ for $S$. voratum CCAC 3869 and $10.0 \%$ for S. microadriaticum CCAC 2475 B (day 12 of immobilized cultivation; Fig. 6).

\section{Effect of temperature on total fatty acids and fatty acid content}

Increase of temperature affected the amounts of total DHA and FAME of both Symbiodinium species similarly (Figs. 7, 8). Specifically, when temperature changed from 17 to $22^{\circ} \mathrm{C}$, the amounts of total DHA and FAME per area increased. However, a further increase in temperature from 22 to $27{ }^{\circ} \mathrm{C}$ caused a decrease in the amounts of total DHA and FAME per area.

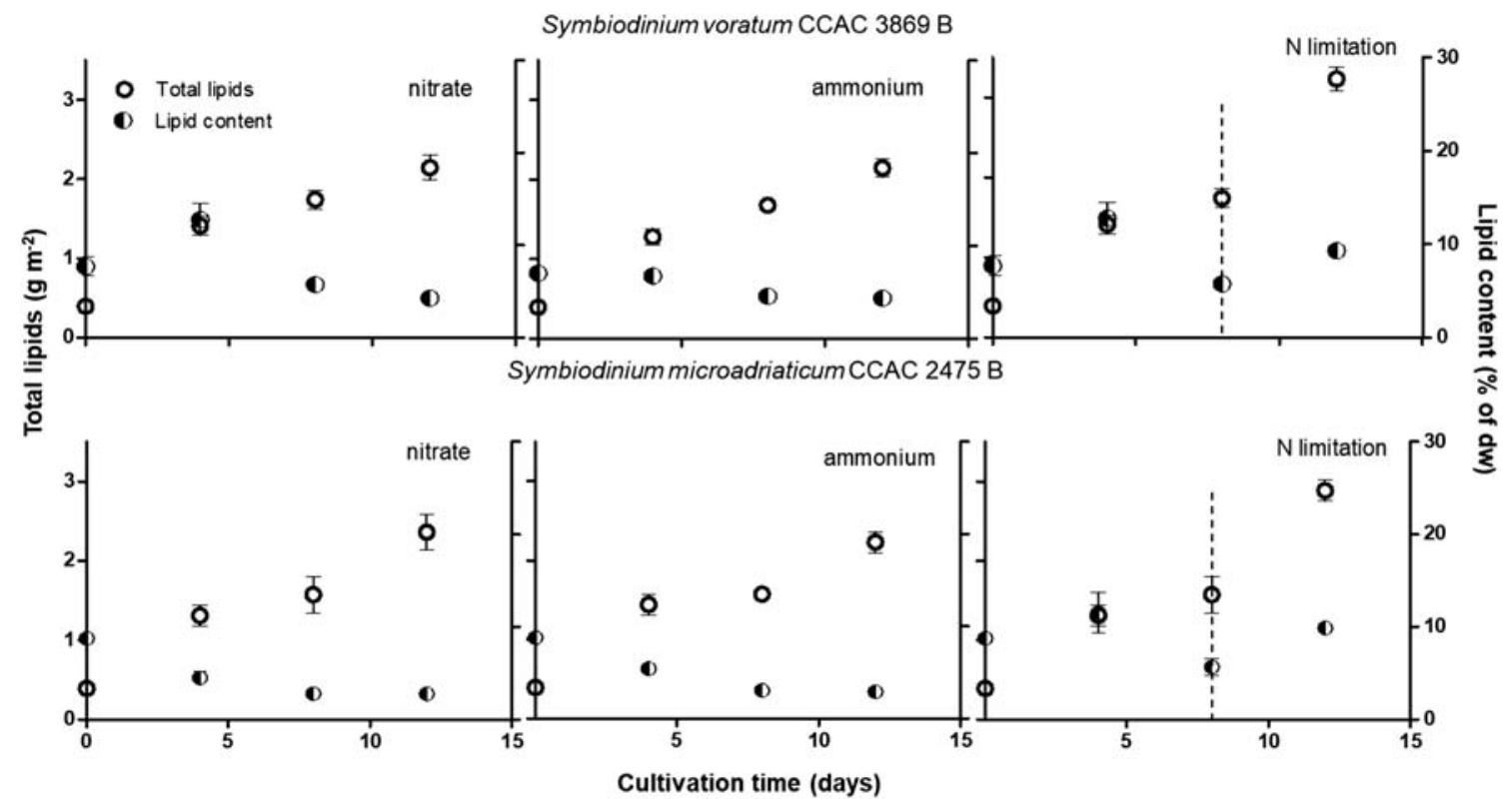

Fig. 6 Total lipids $\left(\mathrm{g} \mathrm{m}^{-2}\right)$ and lipid content (\% of the dry weight) of immobilized Symbiodinium voratum CCAC 3869 B and Symbiodinium microadriaticum CCAC 2475 B cultures in TL-PSBRs within the experimental period under different nitrogen regimes (nitrate, ammonium, nitrogen limitation) at $22{ }^{\circ} \mathrm{C}$. Nitrogen limitation started at day 8 
Symbiodinium voratum CCAC 3869 B
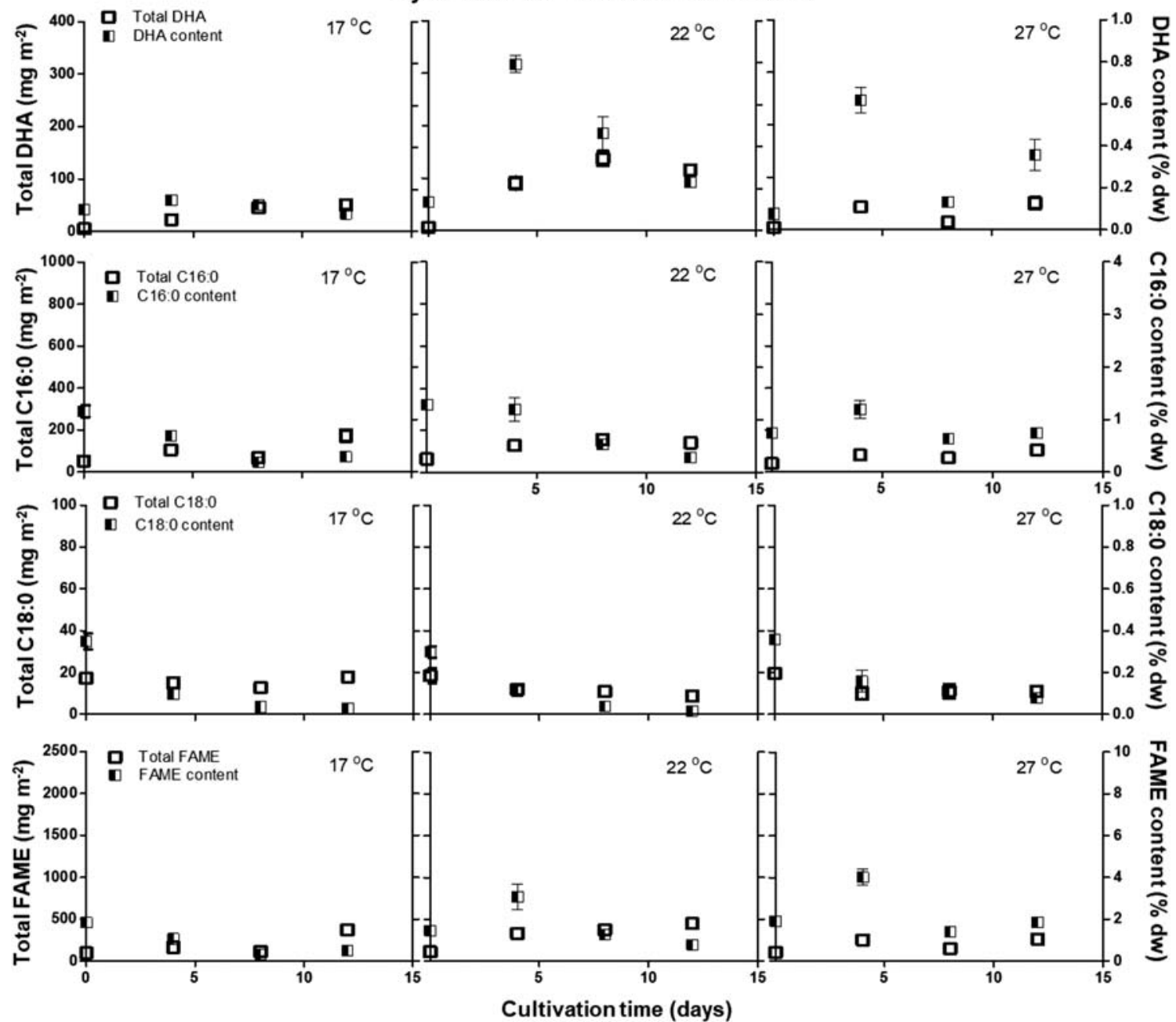

Fig. 7 Total fatty acids $\left(\mathrm{mg} \mathrm{m}^{-2}\right.$ ) and fatty acid contents (\% of the dry weight) of immobilized Symbiodinium voratum CCAC 3869 B cultures in TLPSBRs within the experimental period under different temperatures $\left(17,22\right.$ and $\left.27^{\circ} \mathrm{C}\right)$

Thus, maximum values were observed at $22{ }^{\circ} \mathrm{C}$, with S. voratum CCAC 3869 B reaching $137.4 \mathrm{mg} \mathrm{m}^{-2}$ total DHA and $448.8 \mathrm{mg} \mathrm{m}^{-2}$ total FAME and S. microadriaticum CCAC $2475 \mathrm{~B}$ resulting in $357.3 \mathrm{mg} \mathrm{m}^{-2}$ and $1759.1 \mathrm{mg} \mathrm{m}^{-2}$, respectively (Figs. 7, 8). In the case of total saturated fatty acids, no effect of temperature was observed in S. voratum CCAC 3869 B (Fig. 7), whereas in S. microadriaticum CCAC 2475 B, the amounts of total $\mathrm{C} 16: 0$ and $\mathrm{C} 18: 0$ per area were significantly higher at $22^{\circ} \mathrm{C}$ and $27^{\circ} \mathrm{C}$ compared to $17^{\circ} \mathrm{C}$, especially in the later phases of growth (Fig. 8).

Symbiodinium voratum CCAC 3869 B reached its maximum DHA content at $22{ }^{\circ} \mathrm{C}(0.8 \%$ in the dry weight at day 4 ; Fig. 7). However, maximum FAME, C16:0 and C18:0, content was attained at the highest temperature applied, i.e. at $27{ }^{\circ} \mathrm{C}$ (4.0, 1.2 and $0.2 \%$, respectively; Fig. 7). Likewise, S. microadriaticum CCAC 2475 B demonstrated its maximum DHA content at $22{ }^{\circ} \mathrm{C}(0.6 \%$ in the dry weight at day 4; Fig. 8). The effect of temperature, though, was more pronounced for the saturated fatty acids of this species, with the highest temperature of $27{ }^{\circ} \mathrm{C}$ resulting in increased contents of $\mathrm{C} 16: 0$ and $\mathrm{C} 18: 0$ (3.3 and $0.4 \%$ in the dry weight, respectively; Fig. 8) compared to $S$. voratum CCAC 3869 B.

\section{Effect of nitrogen source/limitation on total fatty acids and fatty acid content}

To investigate the effect of different nitrogen sources on total fatty acids, nitrate and ammonium-based culture media were used. For the experiments of nitrogen limitation, the nitraterich culture medium was replaced by a nitrogen-free medium at day 8 of the immobilized cultivation. It was shown that shifts in the nitrogen source had no effect on the amounts of total fatty acids per area, whereas nitrogen limitation had a positive effect, in particular for S. microadriaticum CCAC 2475 B (Figs. 9, 10). More specifically, S. voratum CCAC 3869 B reached a maximum total DHA of $225.7 \mathrm{mg} \mathrm{m}^{-2}$ with nitrogen limitation, 

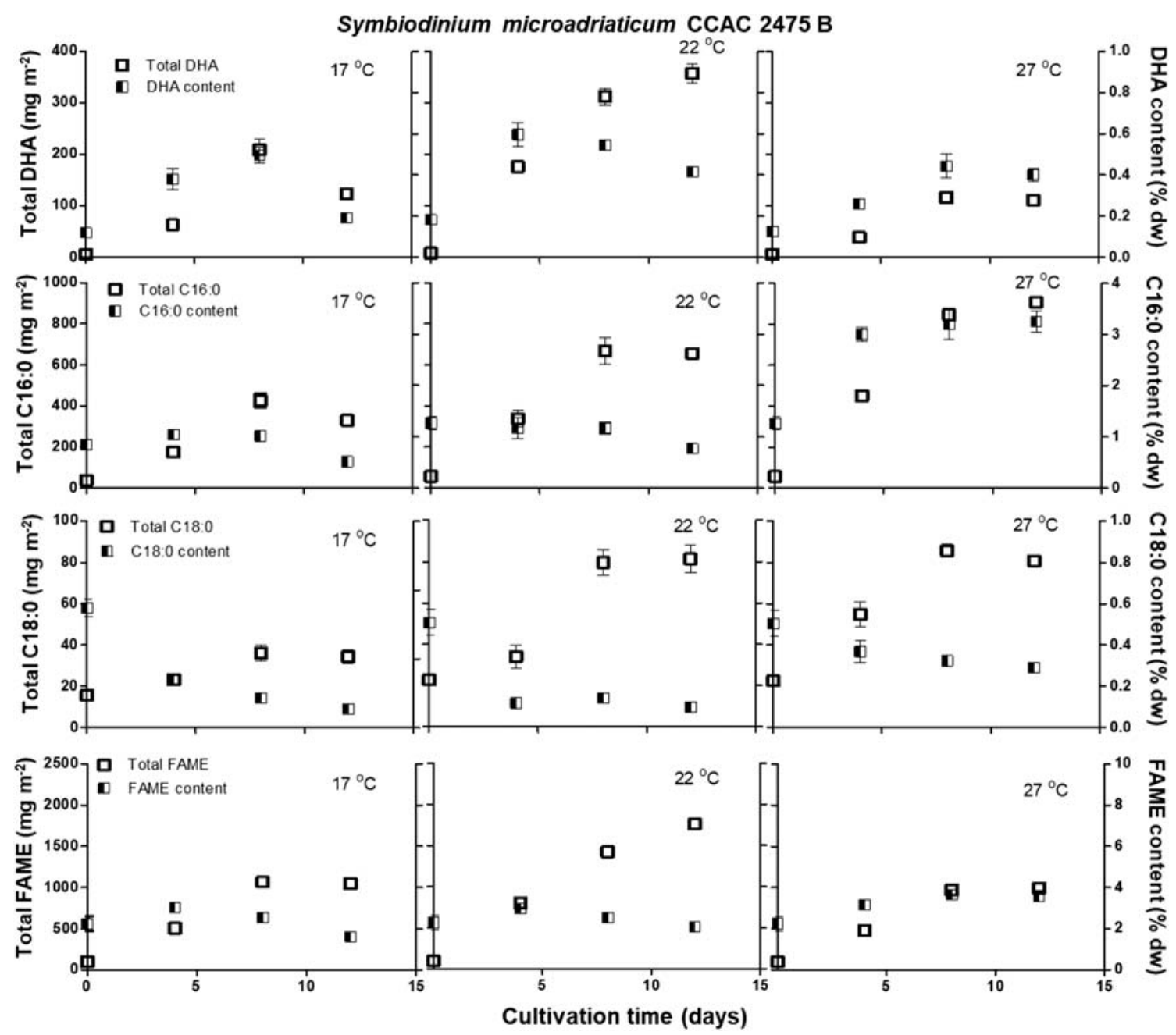

Fig. 8 Total fatty acids $\left(\mathrm{mg} \mathrm{m}^{-2}\right)$ and fatty acid contents (\% of the dry weight) of immobilized Symbiodinium microadriaticum CCAC 2475 B cultures in TL-PSBRs within the experimental period under different temperatures $\left(17,22\right.$ and $\left.27{ }^{\circ} \mathrm{C}\right)$

whereas S. microadriaticum CCAC 2475 B reached $596.7 \mathrm{mg} \mathrm{m}^{-2}$, respectively (Figs. 9, 10). No significant differences were observed for the kinetics, and the maximum values of total C16:0 and C18:0 with the two nitrogen sources were tested, while an increase in amounts was observed with nitrogen limitation (Figs. 9, 10). Regarding total FAME, S. voratum CCAC 3869 B attained maximum values within the narrow range of 420.6-448.8 $\mathrm{mg} \mathrm{m}^{-2}$ (Fig. 9), whereas the maximum total FAME per area for $S$. microadriaticum CCAC 2475 B reached $1759.1 \mathrm{mg} \mathrm{m}^{-2}$ with nitrate, $1473.3 \mathrm{mg} \mathrm{m}^{-2}$ with ammonium and $2250.0 \mathrm{mg} \mathrm{m}^{-2}$ with nitrogen limitation (Figs. 9, 10).

The effect of different nitrogen regimes on fatty acid content of $S$. voratum CCAC 3869 B was insignificant (Fig. 9). In the case of S. microadriaticum CCAC 2475 though, nitrogen limitation had a strong positive effect on the fatty acid contents (Fig. 10). DHA content in the dry weight increased from 0.6 (maximum DHA content with the use of nitrate; Fig. 10) to $2.0 \%$ due to nitrogen limitation. Similarly, FAME content more than doubled from 3.0 to $7.5 \%$ (Fig. 10). Finally, upon nitrogen limitation, the saturated fatty acid contents doubled, with $\mathrm{C} 16: 0$ reaching $2.5 \%$ and $\mathrm{C} 18: 00.4 \%$ of dry weight (Fig. 10).

\section{DHA productivities and maximum values}

Immobilized cultivation of Symbiodinium species in a TLPSBR has shown that $S$. microadriaticum CCAC 2475 B reached significantly higher DHA productivities and maximum DHA values than $S$. voratum CCAC 3869 B under all temperatures and nitrogen regimes tested (Fig. 11). In particular, S. voratum CCAC 3869 B had its lowest DHA productivity when cultivated at $17^{\circ} \mathrm{C}\left(4.9 \mathrm{mg} \mathrm{m}^{-2}\right.$ day $^{-1}$; Fig. 11) and its highest during nitrogen limitation $\left(41.3 \mathrm{mg} \mathrm{m}^{-2}\right.$ day $^{-1}$; Fig. 11). Symbiodinium microadriaticum CCAC 2475 B revealed DHA productivities of 37.9 and $45.2 \mathrm{mg} \mathrm{m}^{-2}$ day $^{-1}$ at $22{ }^{\circ} \mathrm{C}$ with nitrate and ammonium, respectively, whereas lower values were achieved at 17 and $27{ }^{\circ} \mathrm{C}(25.5$ and $13.8 \mathrm{mg} \mathrm{m}^{-2}$ day $^{-1}$, respectively; Fig. 11). However, nitrogen 
Symbiodinium voratum CCAC 3869 B

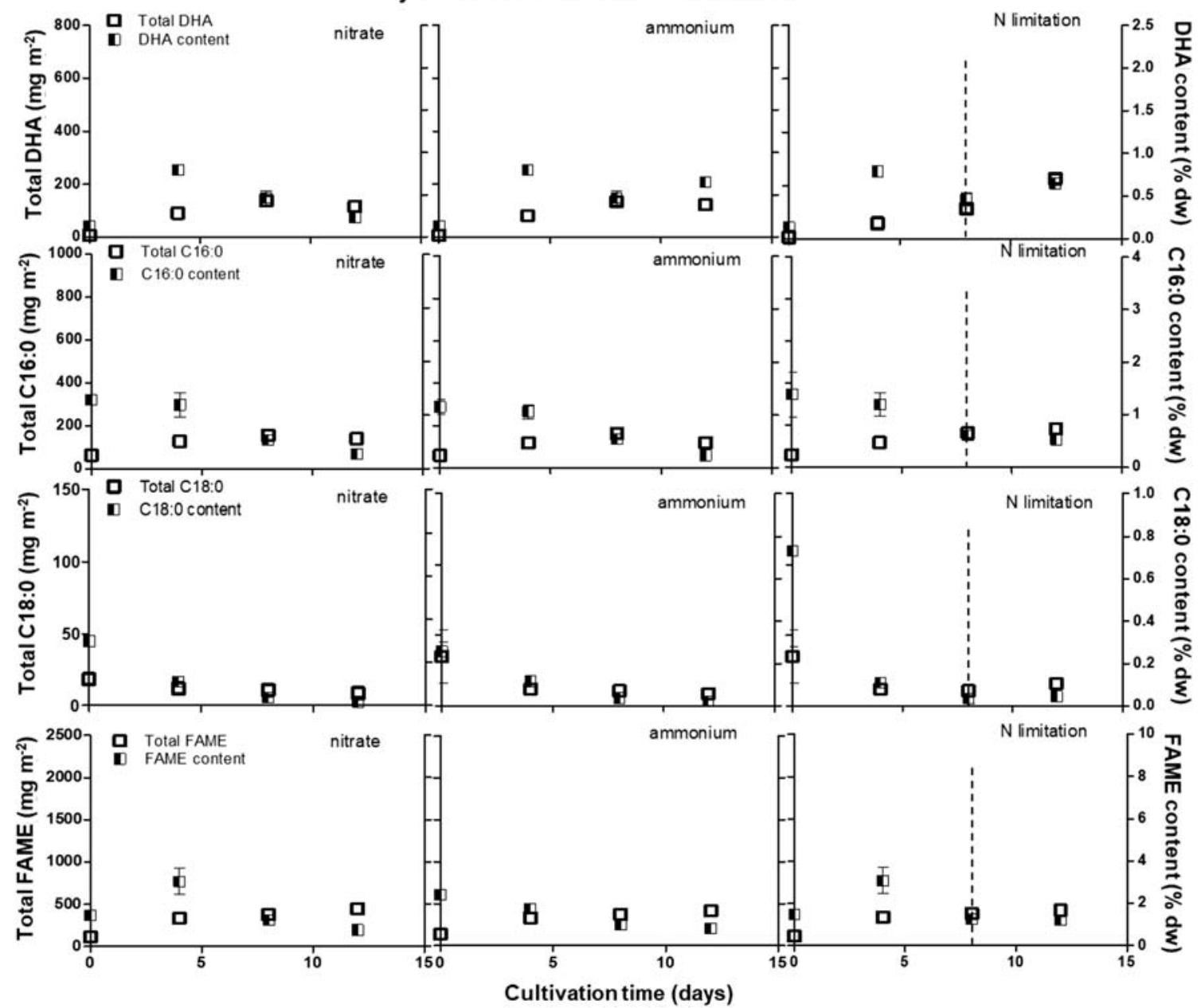

Fig. 9 Total fatty acids $\left(\mathrm{mg} \mathrm{m}^{-2}\right)$ and fatty acid contents (\% of the dry weight) of immobilized Symbiodinium voratum CCAC 3869 B cultures in TL-PSBRs within the experimental period under different nitrogen

limitation enhanced DHA productivity of $S$. microadriaticum CCAC 2475 B which attained the maximum value reported in the present study, i.e. $145.4 \mathrm{mg} \mathrm{m}^{-2}$ day $^{-1}$ (Fig. 11).

A temperature of $22{ }^{\circ} \mathrm{C}$ favoured maximum total DHA for both Symbiodinium species tested, although $S$. microadriaticum CCAC 2475 B reached higher absolute numbers than S. voratum CCAC 3869 B Fig. 11). Ammonium positively affected the maximum total DHA only of $S$. microadriaticum CCAC 2475 (Fig. 11). Nitrogen limitation was also the factor with the strongest effect on maximum DHA values (Fig. 11).

\section{Discussion}

It is well documented that several environmental factors, such as temperature and nutrient concentration, strongly affect the type of fatty acids produced by autotrophic microalgae (Renaud et al. 1995, 2002; Zhu et al. 1997; Lin et al. 2007; regimes (nitrate, ammonium, nitrogen limitation) at $22^{\circ} \mathrm{C}$. Nitrogen limitation started at day 8

Converti et al. 2009; Jónasdóttir 2019). TL-PSBRs allow rapid changes of environmental parameters, such as nutrient composition or temperature, because unlike suspension cultures, the biomass is already separated from the bulk medium by design (Schultze et al. 2015). In the present study, two strains of Symbiodinium, one free-living and one symbiotic, were successfully cultivated, immobilized as biofilms on a TLPSBR. The cultures were further assessed under different temperatures and nitrogen regimes resulting in enhanced DHA productivity.

\section{Biomass growth of dinoflagellates in TL-PSBR}

Cultivation of autotrophic dinoflagellates at a technical scale is restrained by a series of problems related to low growth rates and sensitivity to shear stress (Tang 1996; GarcíaCamacho et al. 2007; Gallardo-Rodríguez et al. 2016). Therefore, a plethora of potentially valuable products from 
Symbiodinium microadriaticum CCAC 2475 B
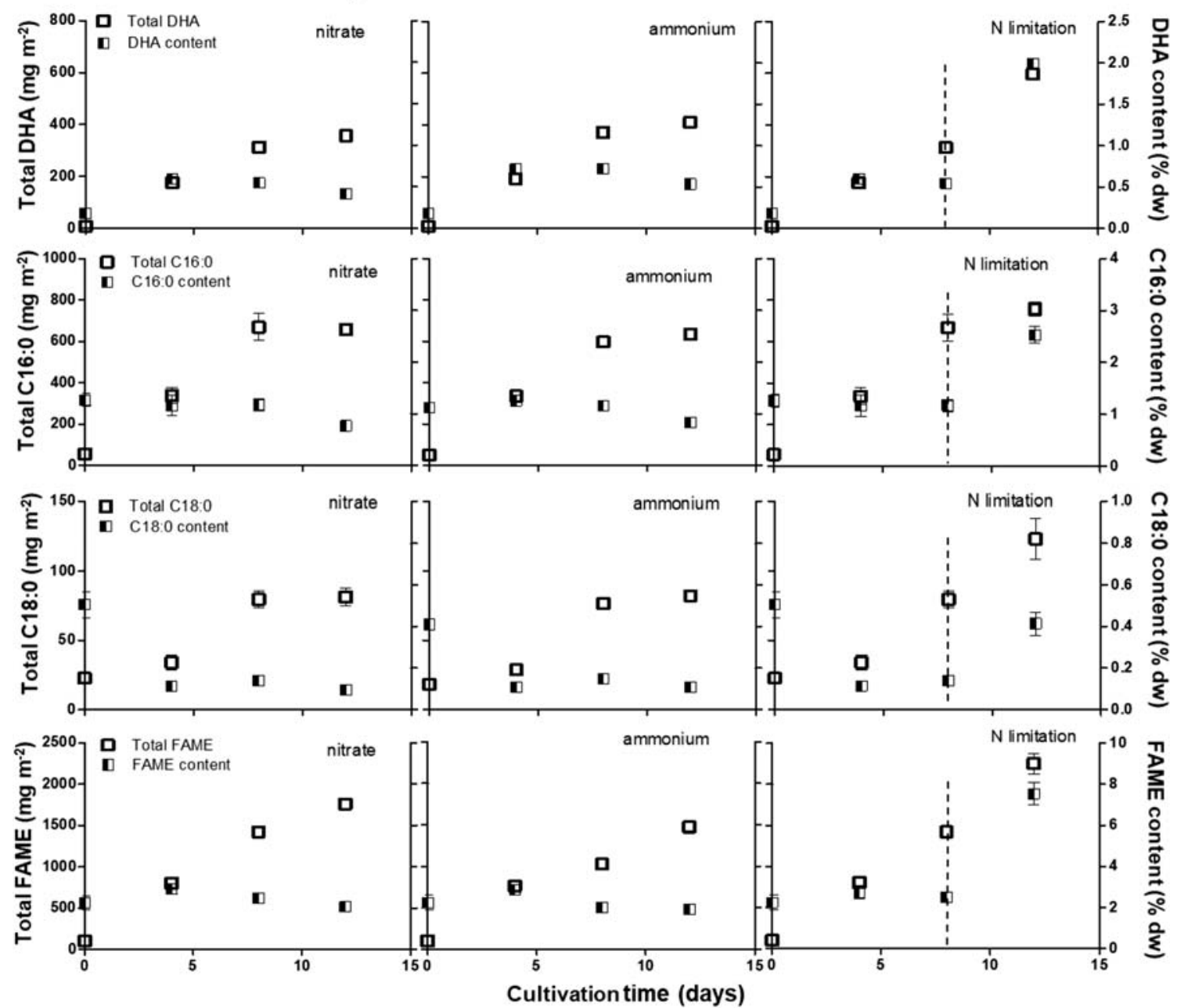

Fig. 10 Total fatty acids $\left(\mathrm{mg} \mathrm{m}^{-2}\right.$ ) and fatty acid contents (\% of the dry weight) of immobilized Symbiodinium microadriaticum CCAC 2475 B cultures in TL-PSBRs within the experimental period under nitrogen

dinoflagellates remains currently unexploited. Recently, immobilized cultivation of dinoflagellates, as an alternative to conventional suspension cultures, was successfully introduced in a TL-PSBR using the peridinin-producing marine dinoflagellate $S$. voratum (Benstein et al. 2014; Langenbach and Melkonian 2019). This technique was adopted in the present study, where 38 autotrophic marine dinoflagellate strains were cultured in a biofilm photobioreactor with a focus on their total lipid and DHA content.

The dinoflagellate strains, provided by the CCAC, were initially screened for their ability to grow immobilized in a 96Well TL-PSBR. Strain-specific information on biomass growth, lipid accumulation and PUFA content was taken into consideration for election of desirable strains and eventually optimization of their cultivation. For reasons that are presumably related to the light stress induced upon inoculation of a very thin biofilm (Nowack et al. 2005), only seven dinoflagellate strains showed significant growth. Indeed, initial biomass density regimes (nitrate, ammonium, nitrogen limitation) at $22^{\circ} \mathrm{C}$. Nitrogen limitation started at day 8

(IBD) is known to play a key role in the growth of autotrophic microalgae in suspension cultures (Wang et al. 2013). Its importance has also been recognized in biofilm photobioreactors, in which growth of autotrophic cells is tightly linked to the "survival game" between photoinhibition and light limitation of photosynthesis (e.g. Schultze et al. 2015; Li et al. 2016). Experiments in bench-scale TL-PSBRs with higher IBDs revealed higher biomass productivities for two of the strains studied, H. niei UTEX LB 1564 and Kryptoperidinium sp. CCAC $4765 \mathrm{~B}$ (results not shown). In contrast, no significant effect of IBD on growth was observed for the Symbiodinium strains tested. Among all dinoflagellates used in the present study, S. voratum CCAC 3869 B and S. microadriaticum CCAC 2475 revealed the highest biomass productivities and thus were selected for further investigation (Fig. 2).

At first, the effect of temperature was tested on growth. Low to medium temperatures, i.e. 17 and $22{ }^{\circ} \mathrm{C}$, resulted in similar values of standing crops and growth rates. None of the 
Fig. 11 DHA productivity $\left(\mathrm{mg} \mathrm{m}^{-2}\right.$ day $^{-1}$ ) and maximum total DHA (mg m ${ }^{-2}$ ) of immobilized Symbiodinium voratum CCAC 3869 B and Symbiodinium microadriaticum CCAC 2475 B cultures in TLPSBRs within the experimental period under different temperatures $\left(17,22\right.$ and $\left.27^{\circ} \mathrm{C}\right)$ and nitrogen regimes (nitrate, ammonium, nitrogen limitation). Nitrogen limitation started at day 8
Symbiodinium voratum CCAC 3869 B

Symbiodinium microadriaticum CCAC 2475 B
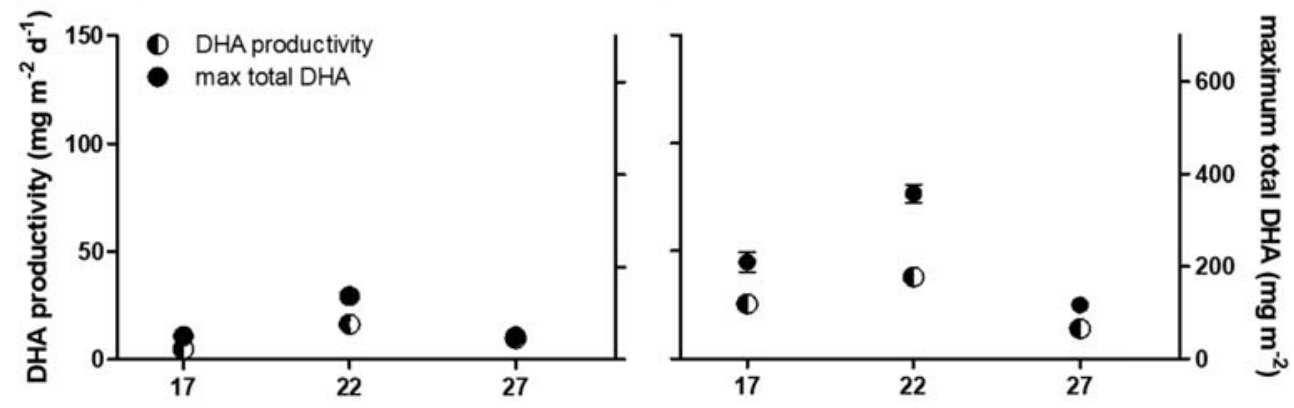

temperature

Symbiodinium voratum CCAC 3869 B Symbiodinium microadriaticum CCAC 2475 B

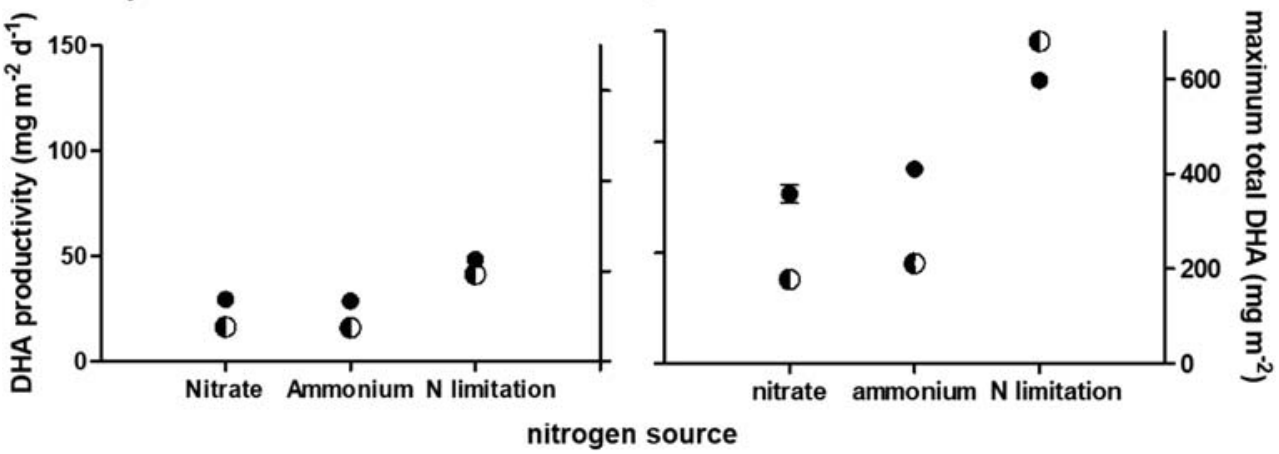

species studied grew well at $27{ }^{\circ} \mathrm{C}$. Effects of different temperatures on growth and photosynthesis of Symbiodinium phylotypes have been extensively studied in recent years in relation to their role in the phenomenon of coral bleaching (Rowan 2004). Although temperature tolerance varies significantly among Symbiodinium phylotypes, limits to growth between 26 and $28{ }^{\circ} \mathrm{C}$ have been frequently reported for both free-living (McBride et al. 2009) and symbiotic (MullerParker et al. 2007) Symbiodinium species/strains.

Subsequently, the effect of different nitrogen regimes was tested on growth. It was shown that the growth response of S. voratum CCAC 3869 B to ammonium was similar to that when using nitrate. On the other hand, ammonium enhanced the standing crop of $S$. microadriaticum CCAC 2475 B when compared to nitrate by about $30 \%$. Previous reports have shown that the host provides symbiotic Symbiodinium species with ammonium as an $\mathrm{N}$ source (Pernice et al. 2012), which may explain the preference for ammonium in S. microadriaticum CCAC 2475 (it was isolated from the sea slug Melibe bucephala). In general, the results of the present study are in accordance with previous reports that marine dinoflagellates can utilize and assimilate various nitrogen sources, including nitrate and ammonium, although the growth response remains species-specific (Taguchi and Kinzie 2001; Leong and Taguchi 2004; Lartigue et al. 2009). Unsurprisingly, nitrogen limitation resulted in the cease of growth for $S$. microadriaticum CCAC 2475 B and deceleration of growth for S. voratum CCAC 3869
B which seems to have slightly larger cellular reserves of nitrogen.

\section{Total lipid content}

In this study, total lipids per area $\left(\mathrm{g} \mathrm{m}^{-2}\right)$ and lipid content (as $\%$ dry weight) of the two dinoflagellate strains were determined during immobilized cultivation in a TL-PSBR (Figs. 5, 6). While total lipids per area increased over time with biomass growth, a decrease in the percentage of lipid content in the biomass was observed after the fourth day of cultivation for both strains under all temperature and nitrogen regimes tested. This could be related to light attenuation and thus a predominance of low light conditions in the deeper layers of the growing biofilm (Li et al. 2016). Low light conditions favour polar, structural lipids over accumulation of storage lipids and generally a lower amount of lipids/cell (Guschina and Harwood 2006; Guedes et al. 2010; Cooper et al. 2011).

Initially, the effect of temperature on lipid content was monitored. An increase above $\left(27^{\circ} \mathrm{C}\right)$ the optimum growth temperature resulted in significantly lower amounts of total lipids per area for both dinoflagellate species compared to lower temperatures in accordance with diminished growth at the high temperature. Regarding temperatures within the optimal growth range $\left(17\right.$ and $\left.22^{\circ} \mathrm{C}\right)$, S. microadriaticum $\mathrm{CCAC}$ 2475 B reached slightly but significantly higher amounts of 
total lipids per area at $17^{\circ} \mathrm{C}$, whereas $S$. voratum CCAC 3869 $\mathrm{B}$ did not reveal significant differences in lipid accumulation between the two temperatures applied.

Nitrogen starvation is one of the most widely used lipid induction techniques and has been applied successfully to various microalgal species (Sharma et al. 2012; Minhas et al. 2016). Here, we tested the effect of nitrogen limitation on the lipid profiles of two Symbiodinium species under immobilized cultivation in a TL-PSBR. Nitrogen limitation triggered a more than double of total lipids per area and lipid content in both Symbiodinium species, indicating that it could be used for optimization of lipid production. Maximum lipid content reported here was $12.8 \%$ for $S$. voratum CCAC 3869 $\mathrm{B}$ and $10.0 \%$ at for $S$. microadriaticum CCAC 2475 B. Even though not yet optimized, these values are in the same range as those previously reported for other dinoflagellates and commercially used microalgal species (Servel et al. 1994; Mansour et al. 1999, 2005; Converti et al. 2009). It is noteworthy that nitrogen depletion was proven to trigger lipid accumulation in our immobilized cultivation system, a result that contradicts the conclusion reached by Schnurr et al. (2013) that nutrient starvation of biofilms is not a desirable method for lipid production by algae.

\section{DHA content and productivity}

A detailed analysis of the complete fatty acid profile of the two dinoflagellates was not the focus of this study, and thus, only total FAME, C16:0 and C18:0, data are presented for comparison. Total DHA amounts $\left(\mathrm{mg} \mathrm{m}^{-2}\right)$ were higher at lower temperatures (17 and $22{ }^{\circ} \mathrm{C}$ ) in $\mathrm{S}$. microadriaticum CCAC 2475 B. On the contrary, the saturated fatty acid (SFAs) $\mathrm{C} 16: 0$ revealed an increase when temperature was raised to $27{ }^{\circ} \mathrm{C}$. This finding has been previously reported for other microalgae, including the heterotrophic DHA-producing Crypthecodinium cohnii (Renaud et al. 1995; Tatsuzawa and Takizawa 1995; Zhu et al. 1997; Jiang and Chen 2000). Exposure to colder temperatures elevates the rigidity of biological membranes, and fatty acids with a high degree of unsaturation are important for the maintenance of membrane fluidity (Harwood 1988). Symbiodinium voratum CCAC $3869 \mathrm{~B}$ was affected differently by the alterations of temperature, with both 17 and $27^{\circ} \mathrm{C}$ resulting in significantly lower DHA yields when compared to $22^{\circ} \mathrm{C}$. One possible explanation is that the two Symbiodinium species exhibit differential acclimation responses (Díaz-Almeyda et al. 2011).

The effect of different nitrogen regimes on DHA production was also investigated. Nitrogen depletion induced significantly higher DHA production in both the free-living and in particular the symbiotic species studied. Nitrogen starvation is an effective "fattening" culture method which has been widely applied in microalgal cultivation (e.g. Sharma et al. 2012). Dinoflagellates incorporate significant amounts of polyunsaturated fatty acids (i.e. DHA) into their cytoplasmic storage lipids in addition to saturated fatty acids. For example, in the heterotrophic dinoflagellate C. cohnii, two-phase fermentation is based exactly on this biological property: one active growth phase in nitrogenreplete medium, during which the lipid content of the biomass is modest, and one stationary phase in nitrogendepleted medium, during which carbon is converted into a storage lipid (TAG) rich in DHA (Wynn et al. 2010). Furthermore, in autotrophic Symbiodinium spp., induction of cytoplasmic lipid droplets enriched in DHA upon nitrogen deprivation has been reported for both the free-living state (Jiang et al. 2014) and in situ in the host Aiptasia pulchella (Weng et al. 2014). In the present study, the maximal DHA productivity for $S$. microadriaticum CCAC 2475 B after 4 days of nitrogen depletion in a TL-PSBR was recorded to be $145.4 \mathrm{mg} \mathrm{m}^{-2}$ day $^{-1}$. Although maximal DHA content in the dry biomass $(2 \%$ in a two-phase experiment in TL-PSBR) has not yet been optimized for S. microadriaticum CCAC 2475 B and is lower than that reported for other autotrophic dinoflagellates grown in suspension (3.4-3.5\% for a long-term semicontinuous culture in an indoor raceway PBR (Molina-Miras et al. 2018; Peltomaa et al. 2019), because of the higher biomass productivity in the TL-PSBR compared to suspension cultivation $\left(6.3 \mathrm{~g} \mathrm{~m}^{-2} \mathrm{~d}^{-1}\right.$ compared to $2.5 \mathrm{~g} \mathrm{~m}^{-2} \mathrm{~d}^{-1}$ in MolinaMiras et al. 2018), the DHA productivity recorded here compares favourably with previous reports. It should be noted that no external addition of $\mathrm{CO}_{2}$ was used in this study; addition of $2 \% \mathrm{CO}_{2}$ has recently been shown to enhance biomass productivity in S. voratum CCAC 0047 (Langenbach and Melkonian 2019). Moreover, pilot-scale TL-PSBRs have been successfully developed and tested in Germany (Naumann et al. 2013; Schultze et al. 2015), Vietnam (Do et al. 2019; Tran et al. 2019), China and Spain (unpubl. data) and are currently considered for scale-up. Porous substrate bioreactors (PSBR), in particular of the twin-layer type (Nowack et al. 2005), have recently attracted considerable attention as an alternative to low density autotrophic suspension cultures (reviews by Mantzorou and Ververides 2019; Podola et al. 2017; Pierobon et al. 2018; Zhuang et al. 2018). The low energy demands for water circulation, as well as the low water footprint and content of the biomass and associated ease of harvesting and processing of biomass, make these systems attractive for applications in bioremediation, biotechnology and biorefinery processes. Hence, we conclude that S. microadriaticum CCAC 2475 B is a promising dinoflagellate for optimization of DHA productivity in a TL-PSBR cultivation system using a two-phase cultivation procedure at $22{ }^{\circ} \mathrm{C}$, including first enhanced growth with ammonium as the nitrogen source and in a second step lipid/DHA accumulation with a nitrogen-depleted culture medium. 
Funding information Open Access funding provided by Projekt DEAL. This work was supported by the University of Cologne and the Bodossaki Foundation (Athens, Greece) with a personal postdoctoral fellowship to A. Tsirigoti.

Open Access This article is licensed under a Creative Commons Attribution 4.0 International License, which permits use, sharing, adaptation, distribution and reproduction in any medium or format, as long as you give appropriate credit to the original author(s) and the source, provide a link to the Creative Commons licence, and indicate if changes were made. The images or other third party material in this article are included in the article's Creative Commons licence, unless indicated otherwise in a credit line to the material. If material is not included in the article's Creative Commons licence and your intended use is not permitted by statutory regulation or exceeds the permitted use, you will need to obtain permission directly from the copyright holder. To view a copy of this licence, visit http://creativecommons.org/licenses/by/4.0/.

\section{References}

Barclay W, Zeller S (1996) Nutritional enhancement of n-3 and n-6 fatty acids in rotifers and Artemia nauplii by feeding spray-dried Schizochytrium sp. J World Aquacult Soc 27:314-322

Benemann JR (1992) Microalgae aquaculture feeds. J Appl Phycol 4: 233-245

Benstein RM, Çebi Z, Podola B, Melkonian M (2014) Immobilized growth of the peridinin-producing marine dinoflagellate Symbiodinium in a simple biofilm photobioreactor. Mar Biotechnol 16:621-628

Bligh EG, Dyer WJ (1959) A rapid method of total lipid extraction and purification. Can J Biochem Physiol 37:911-917

Bourdon J, Bazinet T, Arnason T, Kimpe L, Blais J, White P (2010) Polychlorinated biphenyls (PCBs) contamination and aryl hydrocarbon receptor (AhR) agonist activity of omega-3 polyunsaturated fatty acid supplements: implications for daily intake of dioxins and PCBs. Food Chem Toxicol 48:3093-3097

Breteler WCMK, Koski M, Rampen S (2004) Role of essential lipids in copepod nutrition: no evidence for trophic upgrading of food quality by a marine ciliate. Mar Ecol Prog Ser 274:199-208

Brett M, Müller-Navarra D (1997) The role of highly unsaturated fatty acids in aquatic foodweb processes. Freshw Biol 38:483-499

Broglio E, Jónasdóttir SH, Calbet A, Jakobsen HH, Saiz E (2003) Effect of heterotrophic versus autotrophic food on feeding and reproduction of the calanoid copepod Acartia tonsa: relationship with prey fatty acid composition. Aquat Microb Ecol 31:267-278

Camacho FG, Rodríguez JG, Mirón AS, García MCC, Belarbi EH, Chisti Y, Molina Grima E (2007) Biotechnological significance of toxic marine dinoflagellates. Biotechnol Adv 25:176-194

Chauton MS, Reitan KI, Norsker NH, Tveterås R, Kleivdal HT (2015) A techno-economic analysis of industrial production of marine microalgae as a source of EPA and DHA-rich raw material for aquafeed: research challenges and possibilities. Aquaculture 436: $95-103$

Chisti Y (2007) Biodiesel from microalgae. Biotechnol Adv 25:294-306

Chisti Y (2013) Constraints to commercialization of algal fuels. J Biotechnol 167:201-214

Converti A, Casazza AA, Ortiz EY, Perego P, Borghi MD (2009) Effect of temperature and nitrogen concentration on the growth and lipid content of Nannochloropsis oculata and Chlorella vulgaris for biodiesel production. Chem Eng Process 48:1146-1151

Cooper TF, Lai M, Ulstrup KE, Saunders SM, Flematti GR, Radford B, van Oppen MJH (2011) Symbiodinium genotypic and environmental controls on lipids in reef building corals. PLoS One 6:e20434
Dalsgaard J, St. John M, Kattner G, Müller-Navarra D, Hagen W (2003) Fatty acid trophic markers in the pelagic marine environment. Adv Mar Biol 46:225-340

Díaz-Almeyda E, Thomé PE, El Hafidi M, Iglesias-Prieto R (2011) Differential stability of photosynthetic membranes and fatty acid composition at elevated temperature in Symbiodinium. Coral Reefs 30:217-225

Dixon GK, Syrett PJ (1988) The growth of dinoflagellates in laboratory cultures. New Phytol 109:297-302

Do TT, Ong BN, Nguyen Tran ML, Nguyen D, Melkonian M, Tran HD (2019) Biomass and astaxanthin productivities of Haematococcus pluvialis in an angled twin-layer porous substrate photobioreactor: effect of inoculum density and storage time. Biology 8:68

Fuentes-Grünewald C, Bayliss C, Fonlut F, Chapuli E (2016) Long-term dinoflagellate culture performance in a commercial photobioreactor: Amphidinium carterae case. Bioresour Technol 218:533-540

Gallardo-Rodríguez JJ, Sánchez-Mirón A, García-Camacho F, CerónGarcía MC, Belarbi EH, Chisti Y, Molina Grima E (2009) Causes of shear sensitivity of the toxic dinoflagellate Protoceratium reticulatum. Biotechnol Prog 25:792-800

Gallardo-Rodríguez JJ, López-Rosales L, Sánchez-Mirón A, GarcíaCamacho F, Molina-Grima E, Chalmers JJ (2016) New insights into shear-sensitivity in dinoflagellate microalgae. Bioresour Technol 200:699-705

García-Camacho F, Gallardo-Rodríguez JJ, Sánchez-Mirón A, CerónGarcía MC, Belarbi EH, Molina-Grima E (2007) Determination of shear stress thresholds in toxic dinoflagellates cultured in shaken flasks: implications in bioprocess engineering. Process Biochem 42:1506-1515

Gibson CH, Thomas WH (1995) Effects of turbulence intermittency on growth inhibition of a red tide dinoflagellate, Gonyaulax polyedra stein. J Geophys Res 100:24,841-24,846

Guedes AC, Meireles LA, Amaro HM, Malcata FX (2010) Changes in lipid class and fatty acid composition of cultures of Pavlova lutheri, in response to light intensity. J Am Chem Oil Soc 87:791-801

Guillard RRL, Hargraves PE (1993) Stichochrysis immobilis is a diatom, not a chrysophyte. Phycologia 32:234-236

Guschina IA, Harwood JL (2006) Lipids and lipid metabolism in eukaryotic algae. Prog Lipid Res 45:160-186

Harwood JL (1988) Fatty acid metabolism. Annu Rev Plant Physiol 39: $101-138$

Janssen PJ, Lambreva MD, Plumeré N, Bartolucci C, Antonacci A, Buonasera K, Frese R, Scognamiglio V, Rea G (2014) Photosynthesis at the forefront of a sustainable life. Front Chem 2:36

Jiang Y, Chen F (2000) Effects of temperature and temperature shift on docosahexaenoic acid production by the marine microalge Crypthecodinium cohnii. J Am Oil Chem Soc 77:613-617

Jiang P-L, Pasaribu B, Chen C-S (2014) Nitrogen-deprivation elevates lipid levels in Symbiodinium spp. by lipid droplet accumulation: morphological and compositional analyses. PLoS One 9:e87416

Jónasdóttir SH (2019) Fatty acid profiles and production in marine phytoplankton. Mar Drugs 17:151

Khan MI, Shin JH, Kim JD (2018) The promising future of microalgae: current status, challenges, and optimization of a sustainable and renewable industry for biofuels, feed, and other products. Microb Cell Factories 17

Langenbach D, Melkonian M (2019) Optimising biomass and peridinin accumulation in the dinoflagellate Symbiodinium voratum using a twin-layer porous substrate bioreactor. J Appl Phycol 31:21-28

Lartigue J, Jester EJE, Dickey RW, Villareal TA (2009) Nitrogen source effects on the growth and toxicity of two strains of the ciguateracausing dinoflagellate Gambierdiscus toxicus. Harmful Algae 8: 781-791

Leong SCY, Taguchi S (2004) Response of the dinoflagellate Alexandrium tamarense to a range of nitrogen sources and 
concentrations: growth rate, chemical carbon and nitrogen, and pigments. Hydrobiologia 515:215-224

Leyland B, Leu S, Boussiba S (2017) Are Thraustochytrids algae? Fungal Biol 121:835-840

Li T, Podola B, Melkonian M (2016) Investigating dynamic processes in a porous substrate biofilm photobioreactor - a modeling approach. Algal Res 13:30-40

Lin YH, Chang FL, Tsao CY, Leu JY (2007) Influence of growth phase and nutrient source on fatty acid composition of Isochrysis galbana CCMP 1324 in a batch photoreactor. Biochem Eng J 37:166-176

Liu Y, Tang J, Li J, Daroch M, Cheng JJ (2014) Efficient production of triacylglycerols rich in docosahexaenoic acid (DHA) by osmoheterotrophic marine protists. Appl Microbiol Biotechnol 98:9643

López-Rodríguez M, Céron-García MC, López-Rosales K, GonzálezLópez CV, Molina-Miras A, Ramírez-González A, Sánchez-Míron A, García-Camacho F, Molina-Grima E (2019) Assessment of multi-step processes for an integral use of biomass of the marine microalga Amphidinium carterae. Bioresour Technol 282:370-377

López-Rosales L, García-Camacho F, Sánchez-Mirón A, ContrerasGómez A, Molina-Grima E (2015) An optimisation approach for culturing shear-sensitive dinoflagellate microalgae in bench-scale bubble column photobioreactors. Bioresour Technol 197:375-382

Mahaffey KR, Clickner RP, Jeffries RA (2008) Methylmercury and omega-3 fatty acids: co-occurrence of dietary sources with emphasis on fish and shellfish. Environ Res 10:20-29

Mansour MP, Volkman JK, Jackson AE, Blackburn SI (1999) The fatty acid and sterol composition of five marine dinoflagellates. J Phycol 35:710-720

Mansour MP, Frampton DMF, Nichols PD, Volkman JK, Blackburn SI (2005) Lipid and fatty acid yield of nine stationary-phase microalgae: applications and unusual $\mathrm{C} 24-\mathrm{C} 28$ polyunsaturated fatty acids. J Appl Phycol 17:287-300

Mantzorou A, Ververides F (2019) Microalgal biofilms: a further step over current microalgal cultivation techniques. Sci Total Environ 651:3187-3201

McBride BB, Muller-Parker G, Jakobsern HH (2009) Low thermal limit of growth rate of Symbiodinium californium (Dinophyta) in culture may restrict the symbiont to southern populations of its host anemones (Anthopleura spp.; Anthozoa, Cnidaria). J Phycol 45:855-863

McFadden GI, Melkonian M (1986) Use of Hepes buffer for microalgal culture media and fixation for electron microscopy. Phycologia 25: $551-557$

Mendes A, Reis A, Vasconelos R, Guerra P, da Silva TL (2009) Crypthecodinium cohnii with emphasis on DHA production: a review. J Appl Phycol 21:199-214

Minhas AK, Hodgson P, Barrow CJ, Adholeya A (2016) A review on the assessment of stress conditions for simultaneous production of microalgal lipids and carotenoids. Front Microbiol 7:546

Molina-Miras A, López-Rosales L, Sánchez-Mirón A, Céron-García MC, Seoane-Parra S, García-Camacho F, Molina-Grima E (2018) Longterm culture of the marine dinoflagellate microalga Amphidinium carterae in an indoor LED-lighted raceway photobioreactor: production of carotenoids and fatty acids. Bioresour Technol 265: 257-267

Müller-Navarra DC (2008) Food web paradigms: the biochemical view on trophic interactions. Int Rev Hydrobiol 93:489-505

Muller-Parker G, Pierce-Cravens J, Bingham BL (2007) Broad thermal tolerance of the symbiotic dinoflagellate Symbiodinium muscatinei (Dinophyta) in the sea anemone Anthopleura elegantissima (Cnidaria) from northern latitudes. J Phycol 43:25-31

Nath P, Khozin-Goldberg I, Cohen Z, Boussiba S, Zilberg D (2012) Dietary supplementation with the microalgae Parietochloris incisa increases survival and stress resistance in guppy (Poecilia reticulata) fry. Aquaculture Nutr 18:167-180
Naumann T, Çebi Z, Podola B, Melkonian M (2013) Growing microalgae as aquaculture feeds on twin-layers: a novel solid-state photobioreactor. J Appl Phycol 25:1413-1420

Nestel P, Clifton P, Colquhoun D, Noakes M, Mori TA, Sullivan D, Thomas B (2015) Indications for omega-3 long chain polyunsaturated fatty acid in the prevention and treatment of cardiovascular disease. Heart Lung Circ 24:769-779

Nowack E, Podola B, Melkonian M (2005) The 96-well twin-layer system: a novel approach in the cultivation of microalgae. Protist 156: 239-251

Patil V, Reitan KI, Knutsen G, Mortensen LM, Källqvist T, Olsen E, Vogt G, Gislerød HR (2005) Microalgae as source of polyunsaturated fatty acids for aquaculture. Curr Topics Plant Biol 6:57-65

Peltomaa E, Hällfors H, Taipale SJ (2019) Comparison of diatoms and dinoflagellates from different habitats as sources of PUFAs. Mar Drugs 17:233

Pernice M, Meibom A, Van den Heuvel A, Kopp C, Domart-Coulon I, Hoegh-Guldberg O, Dove S (2012) A single-cell view of ammonium assimilation in coral-dinoflagellate symbiosis. ISME J 6:13141324

Pierobon SC, Cheng X, Graham PJ, Nguyen B, Karakolis EG, Sinton D (2018) Emerging microalgae technology: a review. Sustain Energy Fuels 2:13-18

Pike IH, Jackson A (2010) Fish oil: production and use now and in the future. Lipid Technol 22:59-61

Podola B, Li T, Melkonian M (2017) Porous substrate bioreactors: a paradigm shift in microalgal biotechnology? Trends Biotechnol 35:121-132

Ponikowski P, Voors AA, Anker SD, Bueno H, Cleland JGF, Coats AJS, Falk V, González-Juanatey JR, Harjola VP, Jankowska EA, Jessup M, Linde C, Nihoyannopoulos P, Parissis JT, Pieske B, Riley JP, Rosano GMC, Ruilope LM, Ruschitzka F, Rutten FH, van der Meer P, ESC Scientific Document Group (2016) 2016 ESC guidelines for the diagnosis and treatment of acute and chronic heart failure. Eur Heart J 37:2129-2200

Ren LJ, Ji XJ, Huang H, Qu L, Feng Y, Tong QQ, Ouyang PK (2010) Development of a stepwise aeration control strategy for efficient docosahexaenoic acid production by Schizochytrium sp. Appl Microbiol Biotechnol 87:1649-1656

Renaud SM, Zhou HC, Parry DL, Thinh LV, Woo KC (1995) Effect of temperature on the growth, total lipid content and fatty acid composition of recently isolated tropical microalgae Isochrysis sp., Nitzschia closterium, Nitzschia paleacea, and commercial species Isochrysis sp., (clone T.ISO). J Appl Phycol 7:595-602

Renaud SM, Thinh LV, Lambrinidis G, Parry DL (2002) Effect of temperature on growth, chemical composition and fatty acid composition of tropical Australian microalgae grown in batch cultures. Aquaculture 211:195-214

Rowan R (2004) Thermal adaptation in reef coral symbionts. Nature 430: 742

Ryan L, Symington AM (2015) Algal-oil supplements are a viable alternative to fish-oil supplements in terms of docosahexaenoic acid (22: 6n-3; DHA). J Funct Foods 19:852-858

Schnurr PJ, Espie GS, Allen DG (2013) Algae biofilm growth and the potential to stimulate lipid accumulation through nutrient starvation. Bioresour Technol 136:37-344

Schultze LKP, Simon MV, Li T, Langenbach D, Podola B, Melkonian M (2015) High light and carbon dioxide optimize surface productivity in a twin-layer biofilm photobioreactor. Algal Res 8:37-44

Servel M-O, Claire C, Derrien A, Coiffard L, de Roeck-Holtzhauer Y (1994) Fatty acid composition of some marine microalgae. Phytochemistry 36:691-693

Shah MR, Lutzu GA, Alam A, Sarker P, Chowdhury MAK, Parsaeimehr A et al (2018) Microalgae in aquafeeds for a sustainable aquaculture industry. J Appl Phycol 30:197-213 
Sharma KK, Schuhmann H, Schenk PM (2012) High lipid induction in microalgae for biodiesel production. Energies 5:1532-1553

Shi J, Podola B, Melkonian M (2007) Removal of nitrogen and phosphorus from wastewater using microalgae immobilized on twin layers: an experimental study. J Appl Phycol 19:417-423

Shuba ES, Kifle D (2018) Microalgae to biofuels: 'promising' alternative and renewable energy, review. Renew. Sustain. Energy Rev 81:743-755

Simopoulos AP (2008) The importance of the omega-6/omega-3 fatty acid ratio in cardiovascular disease and other chronic diseases. Exp Biol Med 233:674-688

Singh A, Nigam PS, Murphy JD (2011) Renewable fuels from algae: an answer to debatable land based fuels. Bioresour Technol 102:10-16

Sun SX, Hua XM, Deng YY, Zhang YN, Li JM, Wu Z, Limbu SM, Lu DS, Yin H-W, Wang G-Q, Waagbø R, Frøyland L, Zhang M-L, Du ZY (2018) Tracking pollutants in dietary fish oil: from ocean to table. Environ Poll 240:733-744

Swanson D, Block R, Mousa SA (2012) Omega-3 fatty acids EPA and DHA: health benefits throughout life. Adv Nutr 3:17

Tacon AGJ, Metian M (2008) Global overview on the use of fish meal and fish oil in industrially compounded aquafeeds: trends and future prospects. Aquaculture 285:146-158

Taguchi S, Kinzie RA III (2001) Growth of zooxanthellae in culture with two nitrogen sources. Mar Biol 138:149-155

Tang EPY (1996) Why do dinoflagellates have lower growth rates? J Phycol 32:80-84

Tatsuzawa H, Takizawa E (1995) Changes in lipid and fatty acid composition of Pavlova lutheri. Phytochemistry 40:397-400

Tocher DR, Betancor MB, Sprague M, Olsen RE, Napier JA (2019) Omega-3 long-chain polyunsaturated fatty acids, EPA and DHA: bridging the gap between supply and demand. Nutrients 11:89

Tran H-D, Do T-T, Le T-L, Tran Nguyen M-L, Pham C-H, Melkonian M (2019) Cultivation of Haematococcus pluvialis for astaxanthin production on angled bench-scale and large-scale biofilm-based photobioreactors. Vietnam J Sci Technol Eng 61:61-70

Wang C, Lan CQ (2018) Effects of shear stress on microalgae - a review. Biotechnol Adv 36:986-1002

Wang J, Han D, Sommerfeld MR, Lu C, Hu Q (2013) Effect of initial biomass density on growth and astaxanthin production of Haematococcus pluvialis in an outdoor photobioreactor. J Appl Phycol 25:253-260

Wang X, Fosse HK, Li K, Chauton MS, Vadstein O, Reitan KI (2019) Influence of nitrogen limitation on lipid accumulation and EPA and DHA content in four marine microalgae for possible use in aquafeed. Front Mar Sci 6:95

Weng L-C, Pasaribu B, Lin I-P, Tsai C-H, Chen C-S, Jiang P-L (2014) Nitrogen deprivation induces lipid droplet accumulation and alters fatty acid metabolism in symbiotic dinoflagellates isolated from Aiptasia pulchella. Sci Rep 4:5777

Wynn J, Behrens P, Sundararajan A, Hansen J, Apt K (2010) Production of single cell oils by dinoflagellates. In: Cohen Z, Ratledghe C (eds) Single Cell Oils, 2nd edn. AOCS Press, Champaign, pp 115-129

Zhu CJ, Lee YK, Chao TM (1997) Effects of temperature and growth phase on lipid and biochemical composition of Isochrysis galbana TK1. J Appl Phycol 9:451-457

Zhuang L-L, Yu D, Zhang J, Liu F-f WY-H, Zhang T-Y, Dao G-H, Hu HY (2018) The characteristics and influencing factors of the attached microalgae cultivation: a review. Renew Sust Energ Rev 94:1110 1119

Publisher's note Springer Nature remains neutral with regard to jurisdictional claims in published maps and institutional affiliations. 